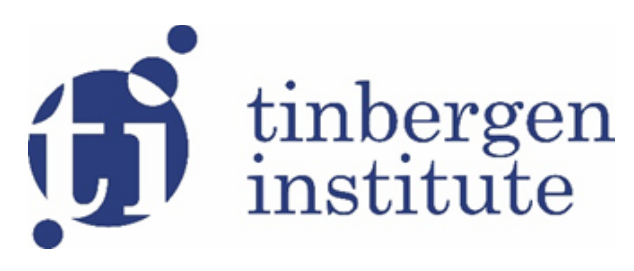

TI 2018-016/IV

Tinbergen Institute Discussion Paper

\title{
Bank Capital Regulation in a Zero Interest Environment
}

\section{Revision: October 2019}

Robin Döttling ${ }^{1}$ 
Tinbergen Institute is the graduate school and research institute in economics of Erasmus University Rotterdam, the University of Amsterdam and VU University Amsterdam.

Contact: discussionpapers@tinbergen.nl

More TI discussion papers can be downloaded at https://www.tinbergen.nl

Tinbergen Institute has two locations:

Tinbergen Institute Amsterdam

Gustav Mahlerplein 117

1082 MS Amsterdam

The Netherlands

Tel.: +31(0)205984580

Tinbergen Institute Rotterdam

Burg. Oudlaan 50

3062 PA Rotterdam

The Netherlands

Tel.: +31(0)10408 8900 


\title{
Bank Capital Regulation in a Zero Interest Environment
}

\author{
Robin Döttling * \\ Rotterdam School of Management, Erasmus University
}

October 2019

\begin{abstract}
How do near-zero interest rates affect optimal bank capital regulation and risktaking? I study this question in a dynamic model, in which forward-looking banks compete imperfectly for deposit funding, but households do not accept negative deposit rates. When deposit rates are constrained by the zero lower bound (ZLB), tight capital requirements disproportionately hurt franchise values and become less effective in curbing excessive risk-taking. As a result, optimal dynamic capital requirements vary with the level of interest rates if the ZLB binds occasionally. Higher inflation and unconventional monetary policy can alleviate the problem, but their overall welfare effects are ambiguous.
\end{abstract}

Keywords. Zero lower bound, search for yield, capital regulation, bank competition, franchise value, monetary policy

JEL classifications. G21, G28, E44, E58

${ }^{*}$ Email: doettling@rsm.nl

I am grateful to David Martinez-Miera, Rafael Repullo, Frédéric Malherbe, Douglas Gale, Tanju Yorulmazer, Javier Suárez, William Diamond, Enrico Perotti, Germán Gutiérrez, Simas Kučinskas, Thomas Philippon, Magdalena Rola-Janicka, Daisuke Ikeda, Carina Mössinger, Hans Degryse, Toni Ahnert, and Wolf Wagner, and Philip Bond for their valuable comments, feedback and suggestions. Seminar participants at the 45th EFA Annual Meeting, OxFIT 2018, IESE Business School Barcelona, the Rotterdam School of Management, Danmarks Nationalbank, the Federal Reserve Board of Governors, INSEAD, the University of Amsterdam, the Tinbergen Institute, the Bank of England, CEMFI, the New York University, the 42nd Simposio of the Spanish Economic Association, the 7th Workshop on Financial Economics (Bonn), the 4th Benelux Banking Day and the Econometric Society European Winter Meeting 2018 also provided useful comments and suggestions. I gratefully acknowledge financial support from the European Central Bank's Lamfalussy Fellowship programme. 


\section{Introduction}

During the past decade, interest rates across advanced economies have been at historical lows, where they are likely to remain for a sustained period of time. Recent contributions show that low interest rates can induce investors to take more risk in a "search for yield" (e.g., Rajan, 2005; Martinez-Miera and Repullo, 2017) and highlight their consequences for macroeconomic outcomes when monetary policy becomes constrained by the zero lower bound (ZLB) (e.g., Eggertsson and Woodford, 2003; Eggertsson and Krugman, 2012). An open question remains how such a low-rate environment affects optimal banking regulation.

This question is important because the ZLB seems to be a particularly relevant constraint for commercial banks. For example, retail deposits have been largely shielded from negative rates in the Eurozone (Heider et al., 2019). ${ }^{1}$ Consequently, low interest rates can undermine the profitability of a banks' deposit franchise, particularly when the ZLB constrains banks from passing on low asset returns to depositors (see further evidence in Section 2). ${ }^{2}$

How do banks react to this environment of near-zero interest rates and compressed margins, and what are the implications for optimal banking regulation? To tackle these questions, I propose a dynamic banking model with money, imperfect deposit competition, endogenous risk-taking, and bank failures. The core of the model builds on established mechanisms in the banking literature that highlight the role of franchise value

\footnotetext{
${ }^{1}$ While there are some cases of banks charging negative rates, a majority is hesitant to do so. This seems to be particularly true for retail deposits, which may more easily substitute towards cash. Perhaps behavioral biases play a role too, as retail customers may perceive negative rates as unfair.

${ }^{2}$ Section 2 presents evidence on the profitability and deposit pricing of U.S. banks in line with this notion. It also shows that fees are unlikely to overcome the problem, as they are not a per-unit price and quantitatively extremely small relative to the growing deposit base of banks. Fees relative to deposits have actually been falling.
} 
(Hellmann et al., 2000) and capital (Holmstrom and Tirole, 1997) for mitigating risktaking incentives. This core is embedded in a dynamic general equilibrium framework, in the spirit of a more recent literature that studies capital regulation in dynamic macro models with banks (e.g., Van den Heuvel, 2008; Martinez-Miera and Suarez, 2014; Begenau, 2016). This approach allows to study optimal dynamic capital requirements in the presence of an occasionally binding ZLB constraint. Yet, the model remains tractable and allows to derive analytically how changes in real and nominal interest rates affect risk-taking incentives, and their interplay with capital regulation.

In the model, there are three agents that operate in a discrete-time, infinite horizon setting. Firms produce output, taking physical capital and labor as inputs. Households supply labor to firms, consume and invest. They can invest directly in firms through a financial market or indirectly via bank equity and deposits. Additionally, households can hold money (cash) that is issued by the government. Deposits and money both carry a convenience yield valued in the household's utility function. Banks set deposit rates under monopolistic competition (Dixit and Stiglitz, 1977), ${ }^{3}$ but nominal deposit rates are subject to a zero lower bound because households can substitute for money. ${ }^{4}$ On the asset side, banks make loans to bank-dependent firms.

The riskiness of bank loans is governed by a banks' monitoring intensity, which banks choose in order to maximize shareholder value. Deposit insurance makes deposits safe, but induces banks to take more risk than is socially optimal. ${ }^{5}$ Failing banks are shut

\footnotetext{
${ }^{3}$ Market power derives from product differentiation, which could be interpreted in terms of a bank's branch locations or its brand. In the appendix, I show robustness to using a circular road model of competition (Salop, 1979).

${ }^{4}$ One could imagine that deposits deliver more convenience utility than cash. In this case, the lower bound is not zero, but $-x \%$. The results in this paper would carry through, with the friction starting to bind at lower rates.

${ }^{5}$ The results in this paper do not rely on the presence of deposit insurance. In Appendix A.4, I present an alternative modeling approach that creates a distortion in risk-taking.
} 
down and therefore stand to lose rents upon failure. In balance, banks trade off the gains from shifting risk on the deposit insurance against the risk of loss of franchise value.

The first part of the analysis uses a simplified static version of the model to show analytically how low interest rates affect risk-taking incentives and their interplay with capital regulation.

The first comparative statics exercise revisits the question whether low interest rates induce banks to take more risk, a behavior referred to as reaching for yield in the previous literature (e.g., Rajan, 2005; Jiménez et al., 2014; Dell Ariccia et al., 2014; Martinez-Miera and Repullo, 2017; Drechsler et al., 2017b; Acharya and Plantin, 2016). The model offers a nuanced answer. I consider changes in the household's discount factor, which affect real interest rates, as well as changes in inflation rates, which affect nominal interest rates, leaving real rates constant. On the one hand, low real and nominal interest rates can erode interest margins, reducing franchise values and inducing more risk-taking. On the other hand, lower discounting of future profits boosts franchise values, thus inducing less risktaking. While the overall effect is ambiguous, I show analytically that the former margin channel dominates whenever the ZLB binds. Intuitively, when banks are constrained in lowering deposit rates, any drop in asset returns eats one-for-one into margins and has a strong effect on profitability. Overall, these results are in line with empirical findings in Heider et al. (2019), who show in a diff-in-diff setting that negative interest rates in the Eurozone have induced banks that rely relatively more on deposit funding to lend to relatively riskier borrowers.

In the model, capital requirements are the main policy tool to curb risk-taking incentives via a "skin in the game" effect (Holmstrom and Tirole, 1997). On the other hand, to the extent that equity is relatively costly, higher capital requirements may reduce a bank's franchise value and thereby increase risk-taking (Hellmann et al., 2000). I show that this negative franchise value effect becomes disproportionately stronger when the 
ZLB binds. As long as the ZLB is slack, banks can react to tighter capital requirements by reducing deposit rates, dampening the negative impact on franchise values (especially if banks have a lot of market power). When the ZLB binds, this margin of adjustment vanishes, such that tighter capital requirements disproportionately hurt franchise values. Consequently, the ZLB not only increases risk-taking incentives, but also makes capital requirements less effective in curbing them.

The second part of the paper uses the full model to analyze the role of dynamics and derive policy implications. The dynamic model relies on a numerical solution of the model, with parameters calibrated to U.S. data. As a source of aggregate variation, the household's discount factor fluctuates stochastically, generating variation in real interest rates over time.

The dynamics highlight that, even if the ZLB is slack in a given period, incentives are affected if the economy may transition to a state with a binding ZLB in the future. This shows that, even after a rate "normalization" (e.g., the Fed started raising rates in 2015), the possibility of falling back to the ZLB may affect incentives today. Moreover, the strength of the effects outlined above depends on how long the ZLB binds in expectation. Intuitively, the longer rates remain low, the more a bank's franchise value is hurt.

What are the implications of these positive results for optimal, welfare-maximizing capital regulation? To answer this question, I solve for optimal dynamic capital requirements, which are allowed to depend on the current aggregate state (i.e., on the level of the household's discount factor and hence real interest rates).

If the ZLB is slack at all times, I find that optimal capital requirements are flat at around $13 \%-14 \%$. In contrast, if the ZLB binds occasionally, optimal requirements vary with the level of interest rates. Perhaps surprisingly, they are lower when the ZLB binds, even though there is more risk-taking at the ZLB. The reason is that the franchise value effect described above makes capital requirements less effective when the ZLB binds, 
motivating a weaker use. In contrast, if the ZLB is slack today, but there is a chance for it to bind in the future, optimal requirements should be tightened. A potentially binding ZLB in the future depresses franchise values today. This increases risk-taking incentives, which should be countered by tightening regulation. In the baseline calibration, optimal capital requirements display strong cyclicality if the ZLB binds occasionally, varying between above $15 \%$ whenever the ZLB is slack and below $10 \%$ at the ZLB.

These findings closely relate to the debate on counter-cyclical regulation, where macroprudential measures are adjusted over the credit cycle to build resilience in good times. In the literature, the case for counter-cyclical requirements is often made in models with welfare-relevant pecuniary externalities or aggregate demand externalities (e.g., Korinek and Simsek, 2016; Farhi and Werning, 2016; Gersbach and Rochet, 2017; Jeanne and Korinek, 2018). ${ }^{6}$ In contrast, the rationale here is relevant even absent any such frictions, and solely depends on the ability of banks to adjust deposit rates in response to tightening regulation. Thus, the model delivers a novel rationale for "counter-cyclical" capital regulation, distinct from the traditional view.

The franchise value effect at the ZLB is also relevant for the debate on whether monetary policy should target financial stability. Some commentators argue that monetary policy should focus on targeting inflation and let macro-prudential policies take care of financial stability (e.g. Bernanke, 2015). However, if very low interest rates undermine the effectiveness of prudential policies, the two cannot be set independently. For example, a higher inflation target can make capital requirements more effective by alleviating the ZLB problem.

However, a higher inflation target may not be desirable or difficult to implement, as highlighted by the experiences in Japan and the Eurozone. As an alternative unconventional monetary policy measure, I consider a subsidized refinancing operation. This

\footnotetext{
${ }^{6}$ The argument in the policy debate is that buffers built up in good times should be available to be used in bad times (e.g. Goodhart et al., 2008), and relies on frictions to raising equity.
} 
policy resembles the ECB's LTRO program, which provides cheap funding to banks at negative interest rates. Subsidized refinancing operations can alleviate the strain on interest margins and improve profitability, thereby restoring franchise values and prudence incentives. However, the overall welfare implications of such policies are ambiguous, as they induce banks to grow too big in equilibrium relative to financial markets.

The paper contributes to a broad range of literature across finance and macroeconomics. The notion that franchise value affects risk-taking follows a long tradition in the banking literature (e.g. Hellmann et al., 2000; Perotti and Suarez, 2002; Repullo, 2004; Boyd and De Nicolo, 2005; Martinez-Miera and Repullo, 2010). There is some debate whether higher competition leads to more or less risk-taking. For example, Boyd and De Nicolo (2005) show that, if the moral hazard problem is placed at the borrower, more bank competition can actually reduce risk-taking incentives of borrowers. The mechanism here is robust, whether the risk shifting problem is placed at the borrower or the bank. When asset returns fall and deposit rates are constrained by the ZLB, the total spread between asset returns and deposit rates has to decline, translating into lower margins for borrowers and banks, making the risk shifting more severe.

To the best of my knowledge, this paper is the first to incorporate this "competition stability" framework in a dynamic macro-banking model, thereby connecting the earlier banking literature with a more recent strand that studies capital regulation in dynamic macro models with banks, such as Van den Heuvel (2008), Repullo and Suarez (2012), Martinez-Miera and Suarez (2014), Malherbe (2015), Begenau (2016), Davydiuk (2017). None of these frameworks considers a monetary economy or imperfect deposit competition. This paper contributes by analyzing how optimal regulation interacts with bank competition, the ZLB, and unconventional monetary policy.

Thereby, the paper also relates to recent empirical literature that studies the relation between monetary policy and bank competition (Drechsler et al., 2017a; Scharfstein and 
Sunderam, 2015; Xiao, 2017). Drechsler et al. (2018) and Hoffmann et al. (2017) show that market power in deposit markets allows banks to reduce the interest rate risk inherent in maturity transformation. The model in this paper builds on these findings. As long as the ZLB is slack, banks can pass on changes in interest rates to depositors and maintain stable margins. The core results rely on the insight that this mechanism breaks down once the zero lower bound distorts deposit pricing. This notion is consistent with event studies around monetary policy announcements, which find that falling interest rates negatively affect bank market values if and only if the ZLB binds (Ampudia and Van den Heuvel, 2018; English et al., 2018).

Closely related, Brunnermeier and Koby (2018) introduce the concept of a "reversal rate" below which monetary policy becomes ineffective. Similarly, Wang (2018) and Eggertsson et al. (2019) show that the transmission of monetary policy pass-through may be dampened in a low-rate environment. While these contributions also highlight the negative effect of low interest rates on bank profitability, this paper has a distinct focus on banking regulation and risk-taking.

Finally, this paper relates to the macroeconomic literature on the zero lower bound and liquidity traps (e.g., Keynes, 1936; Krugman, 1998; Eggertsson and Woodford, 2003; Eggertsson and Krugman, 2012; Guerrieri and Lorenzoni, 2017). While this literature focuses on monetary and fiscal policy, the contribution of this paper is to show that the ZLB may also constrain the effectiveness of prudential regulation.

The rest of the paper is organized as follows. Section 2 presents motivating evidence. Section 3 describes the model setup and equilibrium and concludes with a critical discussion of the model's frictions. Section 4 uses a static version of the model to derive analytical results on how changes in nominal and real interest rates affect risk-taking and capital regulation. Sections 5 and 6 utilize the full dynamic version of the model to highlight the role of expectations and to solve for optimal capital regulation with an 

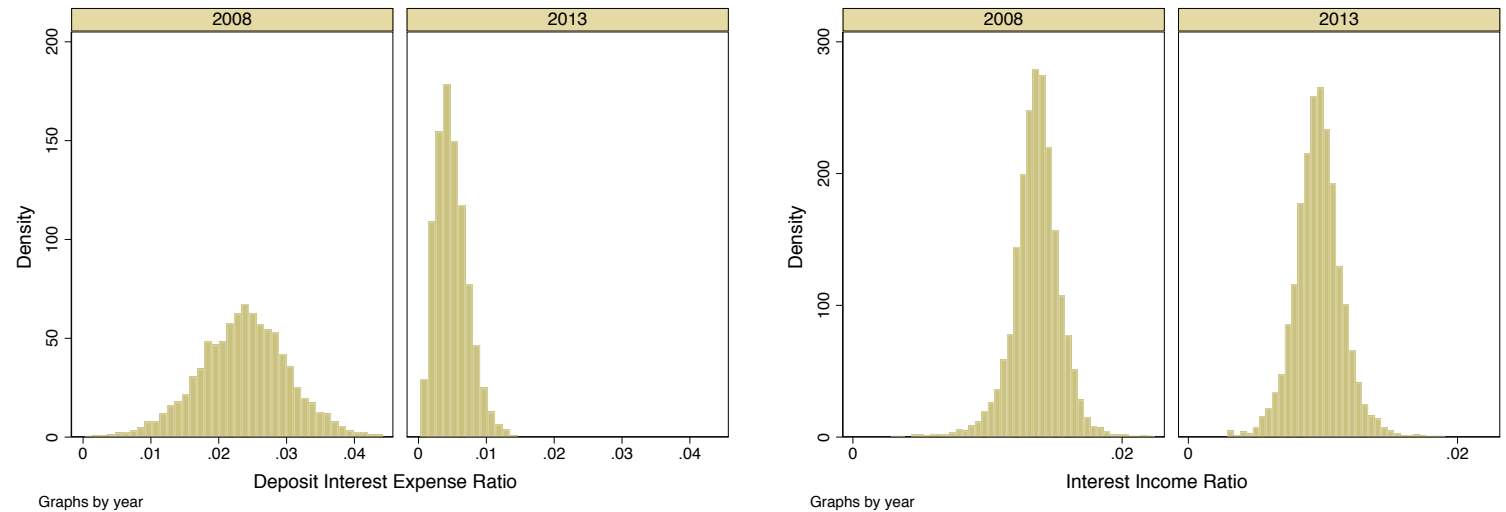

Figure 1: For the years 2008 and 2013, the left panel plots the cross-sectional distribution of deposit interest expense per unit of deposit funding across U.S. banks in the Call Reports data. The right panel plots the distribution of interest income to total assets.

occasionally binding ZLB constraint. Section 6 also discusses how optimal regulation interacts with (unconventional) monetary policy. Finally, Section 7 concludes.

\section{Motivating Evidence}

This section summarizes three motivating empirical facts: (i) banks are hesitant to pass on negative interest rates to depositors; (ii) fees are too small relative to the deposit base of banks to overcome the problem and falling; (iii) as the ZLB started binding in 2009, bank profitability has decreased, in particular for banks that rely most on deposit funding.

For the years 2008 and 2013, i.e. before and after the Fed Funds rate dropped to zero, Figure 1 plots the cross-sectional distribution of U.S. banks' deposit interest expense per unit of deposit funding in the Call Reports data. ${ }^{7}$ Relative to 2008, the shape of the distribution in 2013 is much more right-skewed, suggesting a distortion in deposit pricing as interest rates bunch near zero. This notion is confirmed by FDIC data showing the

\footnotetext{
${ }^{7}$ Due to the short maturity of deposits, this ratio is a good approximation for the current interest rate a bank offers on deposits.
} 

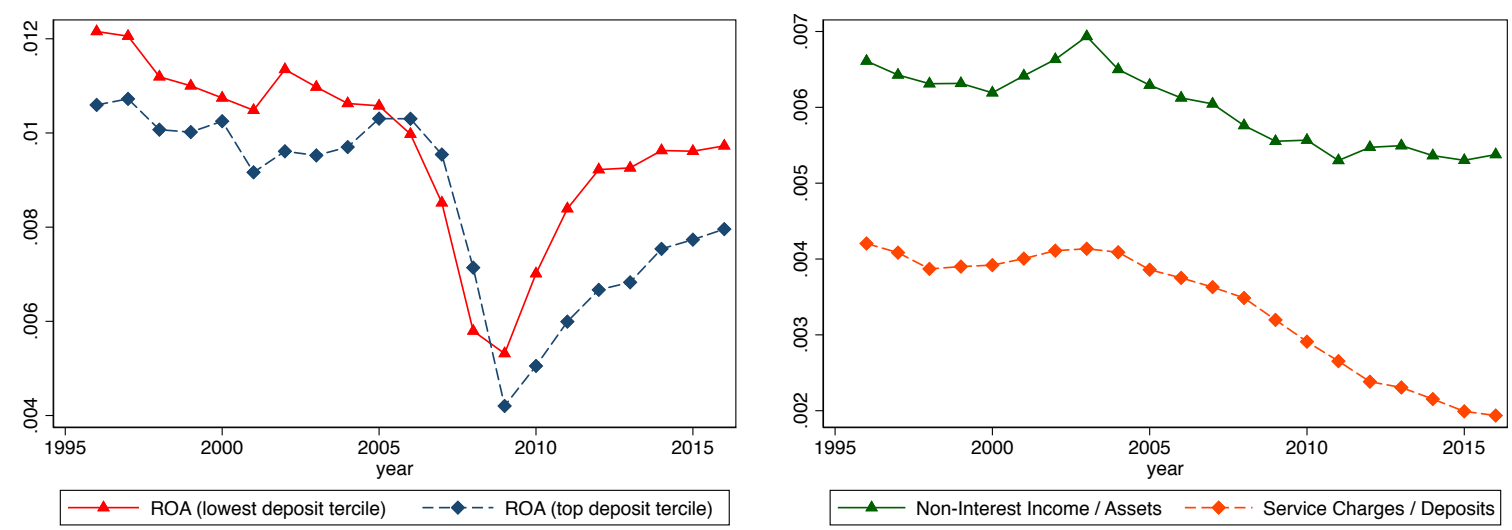

Figure 2: The left panel plots the median ROA (net income over assets), separately for banks in the top and bottom tercile of the deposits / assets distribution in the Call Reports data. The right panel plots non-interest income per unit of assets, as well as service charges per unit of deposits for the median U.S. bank.

average rate on savings accounts has been near zero since 2009. ${ }^{8}$ Heider et al. (2019) find similar evidence for the Eurozone, suggesting many banks are unable or unwilling to lower retail deposit rates into negative territory, even when interbank rates fall below zero. $^{9}$ In contrast, the right panel of Figure 1 shows the shape of the distribution of interest income has not changed.

Even if banks are unable to set negative interest rates on deposits, they may be able to do so effectively by increasing fees. By revealed preference, if the two were equivalent, banks should have charged fees rather than interest rates also away from the ZLB. Arguably, the problem is that, unlike interest rates, fees are not proportional to an account's balance. Already on a low level, service charges on deposits earn a small number, below $0.4 \%$ relative to deposits before 2008. Perhaps surprisingly, this number has been decreasing further, dropping to $0.2 \%$ in 2015 (Figure 2). While banks have been increasing fees (Azar et al., 2016), at the same time, more deposits have been flowing into the banking system. Intuitively, in a low interest environment, households gain little from

\footnotetext{
${ }^{8}$ See the FDIC website: https://www.fdic.gov/regulations/resources/rates/previous.html

${ }^{9}$ Anecdotal evidence suggests that the reason banks are hesitant to set negative interest rates on retail deposits is that they are concerned about triggering a bank run.
} 
hunting yield in other investment opportunities and might as well store their savings in deposit accounts that guarantee absolute safety.

As deposit rates are bounded by zero, and fees and other forms of non-interest income are small and falling, the overall profitability of banks has suffered. Figure 2 shows the ROA of U.S. banks has been significantly lower since the ZLB started binding in 2009 . The figure also shows the drop in ROA is concentrated among banks that rely most on deposits funding that, arguably, are most exposed to the ZLB constraint. In contrast, the ROA of banks in the lowest tercile of the distribution has recovered to near pre-crisis levels.

Overall, the evidence suggests that the zero lower bound on deposit rates binds and that it has a negative effect on interest margins and bank profitability. Motivated by this evidence, the rest of this paper develops a model to understand how the zero lower bound affects bank risk-taking incentives and capital regulation.

\section{Model Setup}

Time runs discretely from $t=0, \ldots, \infty$, and there is a representative household, a representative firm, and a unit mass of banks.

The flow diagram in Figure 3 gives an overview of the model and summarizes the timing within a period $t$. In the beginning of period $t$ (stage $\mathrm{A}$ ), firms produce output using physical capital and labor as inputs and pay households and banks a return on their investments made at $t-1$. Banks use the proceeds to repay depositors and pay a net dividend, which may take negative values if banks raise new equity. Firms pay a wage to households.

Afterwards (stage B), households consume and new investments are made. Households have access to a direct investment via financial markets. These investments are 


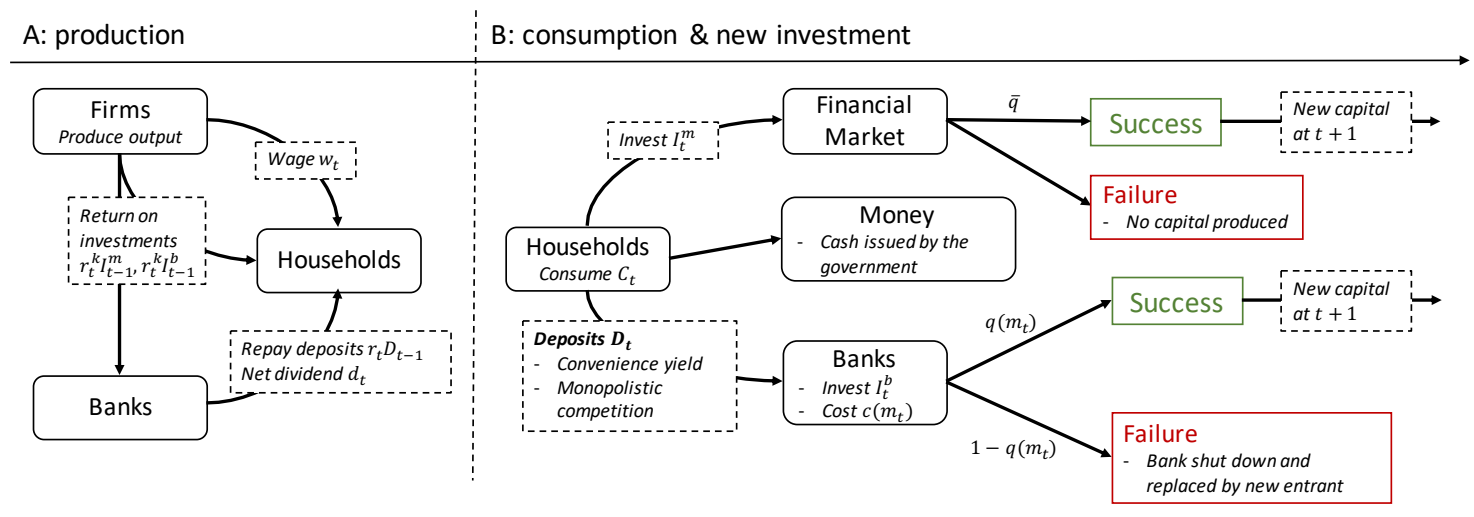

Figure 3: Flow diagram summarizing the within-period timing.

exposed to idiosyncratic risk and create new physical capital in the following period with probability $\bar{q}$. With probability $1-\bar{q}$, the investment fails and no new capital is created. Households can also invest in bank deposits or government-issued money (cash). Deposits and money are special, because they have a non-pecuniary convenience yield captured in the household's utility function. ${ }^{10}$ Both are safe assets because the government can back money by raising taxes, and deposits are protected by deposit insurance. This set of modeling assumptions allows for a tractable introduction of money and a zero lower bound, similar to Korinek and Simsek (2016).

Banks set deposit rates under monopolistic competition (Dixit and Stiglitz, 1977), but nominal rates cannot go negative, because deposits and money are perfect substitutes, and money pays a fixed nominal return of $0 .{ }^{11}$ The nominal deposit rate between $t$ and $t+1$ is denoted $i_{t+1}^{d}$. Real deposit rates are denoted $r_{t+1}^{d}=i_{t+1}^{d} / \pi_{t+1}$, where $\pi_{t+1}$ is the

${ }^{10}$ The banking literature has identified several micro-foundations that motivate this assumption. Because bank debt is information-insensitive, it protects depositors from better informed traders (Gorton and Pennacchi, 1990; Dang et al., 2017). Its demandability may incentivize monitoring (Diamond, 1984) and facilitate the transformation of risky long-term assets into liquid and safe claims (Diamond and Dybvig, 1983; Ahnert and Perotti, 2017). Moreover, banks invest into ATM networks and electronic payment infrastructure that make deposits a convenient medium of exchange.

${ }^{11}$ Deposits may be a more convenient medium of exchange, which would results in a "-x\%" lower bound. Perfect substitutability is in line with the empirical evidence that banks refrain from setting negative retail deposit rates. 
gross inflation rate between $t$ and $t+1$. Real deposit rates cannot fall below $1 / \pi_{t+1}$, the real return on money.

On the asset side, banks invest in loans to a bank-dependent sector. These loans are modeled as a second investment technology that creates physical capital for the next period. ${ }^{12}$ Technologically, the physical capital created by banks is equivalent to that created via financial markets, and both earn the same real gross rental rate $r_{t}^{k}$ when rented to firms. For simplicity, capital fully depreciates after production.

Bank investments are subject to some idiosyncratic risk, which is governed by a bank's monitoring intensity $m_{t}$. Thus, in the model banks fulfill a dual role. On the asset side, their monitoring skill can make loans safer than direct financial market investments. On the liability side, banks create liquid, money-like assets valued by households. Banks are subject to a regulatory capital requirement that limits the leverage they can take.

Agents can also trade bonds with a nominal rate $i_{t+1}^{b}$, and real rate $r_{t+1}^{b}=i_{t+1}^{b} / \pi_{t+1}$. As shown below, bonds are in zero net supply because the government runs a balanced budget. In the following, I describe the individual elements of the model in more detail, solve the problem of firms, households, and banks, and define the equilibrium.

\subsection{Firms}

A representative, profit-maximizing firm operates a Cobb-Douglas production technology that produces output using capital $K_{t}$ and labor $N_{t}$ as the input,

$$
F\left(K_{t}\right)=K_{t}^{\alpha} N_{t}^{1-\alpha}
$$

Capital is owned by households and banks, and firms rent capital at a real rental rate $r_{t}^{k}$, and hire labor at a real wage $w_{t}$. Thus, firms solve a static maximization problem, and

\footnotetext{
${ }^{12}$ In the real world, banks lend to firms which in turn make physical investments. Leaving out this extra layer of capital producing firms is equivalent to assuming that there are no frictions between firms and banks.
} 
capital and labor are compensated according to their marginal productivity:

$$
\begin{aligned}
& r_{t}^{k}=F_{K}\left(K_{t}, N_{t}\right), \\
& w_{t}=F_{N}\left(K_{t}, N_{t}\right) .
\end{aligned}
$$

Firms make zero profits because the production function has constant returns to scale.

\subsection{Household Problem and Deposit Demand}

An infinitely-lived, representative household maximizes lifetime utility over consumption $C_{t}$ and liquidity services $X_{t}=M_{t}+D_{t}$, where $M_{t}$ are real money balances, and $D_{t}$ are deposits.

Households have a preference for different varieties of bank deposits indexed by $i \in$ $[0,1]$. Different varieties could represent a bank specializing in online banking, a big international bank with a prestigious brand, or a local bank with personal relations between clients and advisors. Alternatively, one can think of banks differentiating spatially, and varieties representing different locations. Following Dixit and Stiglitz (1977), this preference is modeled by expressing $D_{t}$ as a CES composite of varieties $D_{t, i}{ }^{13}$

$$
D_{t}=\left[\int_{0}^{1} D_{t, i}^{\frac{\eta-1}{\eta}} d i\right]^{\frac{\eta}{\eta-1}} .
$$

Product differentiation gives rise to market power, the degree of which is governed by the elasticity of substitution $\eta$. Higher values of $\eta$ indicate greater ease of substitutability between varieties, implying lower market power. I assume that $\eta>1$, such that deposits of different banks are substitutes.

\footnotetext{
${ }^{13}$ Arguably, bank market power is not only driven by product differentiation, and for example customer stickiness due to search frictions and switching costs are likely important determinants. Appendix A.3 shows that using a circular road model of competition (Salop, 1979) yields very similar deposit demand and equilibrium deposit rates, and that the key results are robust to this alternative model of competition. The key advantage of the monopolistic competition model is its tractability in general equilibrium. The model is commonly used in the macro literature, and has recently gained popularity in the banking literature (e.g. Drechsler et al., 2017a).
} 
Bank deposits are insured by the government, which funds the deposit insurance by real lump-sum taxes $T_{t}{ }^{14}$ Investments in the financial market are denoted $I_{t}^{m}$. These investments succeed with probability $\bar{q}$, in which case they create capital goods that can be rented to firms in the following period. In case of failure, no capital is produced. This risk is idiosyncratic, such that in aggregate direct investments produce $\bar{q} I_{t}^{m}$ units of capital in the next period.

Households are the owners of firms and banks, and banks make a net dividend payment $d i v_{t}$, which may take negative values when raising new equity. Households supply one unit of labor inelastically to firms and earn a real wage $w_{t}$.

In the dynamic model, the household's discount factor $\beta_{t}$ evolves according to a twostate Markov process. At the beginning of each period, households learn whether $\beta_{t}=\beta_{H}$, resulting in high real interest rates (state $s=H$ ), or $\beta_{t}=\beta_{L}>\beta_{H}$, resulting in low interest rates (state $s=L$ ). The probability of transitioning from state $s$ to $s^{\prime}$ is denoted $P_{s s^{\prime}}$.

Utility is linear in consumption $C_{t}$ and concave in liquidity services $X_{t}$, and households solve

$$
\begin{aligned}
& \max _{C_{t}, I_{t}^{m}, M_{t}, B_{t}, D_{t, i}} \mathbb{E}_{0} \sum_{t=0}^{\infty}\left(\prod_{\tau=0}^{t-1} \beta_{\tau}\right)\left[C_{t}+\gamma v\left(X_{t}\right)\right] \\
& \text { with } X_{t}=M_{t}+\left[\int_{0}^{1} D_{t, i}^{\frac{\eta-1}{\eta}} d i\right]^{\frac{\eta}{\eta-1}}, \\
& \text { s.t. } C_{t}+I_{t}^{m}+M_{t}+B_{t}+\int_{0}^{1} D_{t, i} d i= \\
& r_{t}^{b} B_{t-1}+r_{t}^{k} \hat{I}_{t-1}^{m}+\frac{M_{t-1}}{\pi_{t}}+\int_{0}^{1} r_{t, i}^{d} D_{t-1, i} d i+d i v_{t}+w_{t} N_{t}-T_{t}, \\
& D_{t, i} \geq 0 \forall i, M_{t} \geq 0, I_{t}^{m} \geq 0
\end{aligned}
$$

Here, $\gamma \geq 0$ measures the household's preference for liquidity services, and $v\left(X_{t}\right)=$

\footnotetext{
${ }^{14}$ While a realistic real-world feature, none of the mechanisms in this paper rely on the presence of deposit insurance. What matters is that there is some distortion that induces banks to take excessive risk. Appendix A.4 shows an alternative modeling approach that results in the same distortion as deposit insurance, but where monitoring is not contractible and chosen sequentially.
} 
$\log \left(X_{t}\right)$ is the "convenience" utility households derive from cash and deposits. The real deposit rate offered by bank $i$ is denoted $r_{t, i}^{d}$, and $q_{t-1, i}$ is the success probability of bank $i$, which is endogenous. $\hat{I}_{t-1}^{m}=I_{t-1}^{m}$ if a household's financial market investment is successful and $\hat{I}_{t-1}^{m}=0$ otherwise. The first constraint is the household's budget constraint, and the remaining constraints are non-negativity constraints for deposits, money and financial market investments. ${ }^{15}$

First Order Conditions. The first-order conditions with respect to $B_{t}$ and $I_{t}^{m}$ yield an Euler equation and a no-arbitrage condition between bonds and financial market investments

$$
\begin{aligned}
r_{t+1}^{b} \beta_{t} & =1, \\
r_{t}^{b} & =\bar{q} r_{t}^{k} .
\end{aligned}
$$

Next to the financial market, households invest in bank deposits. The demand for deposits of bank $i$ can be derived from the first-order condition with respect to $D_{t, i}$ :

$$
D_{t, i}\left(r_{t+1, i}^{d}\right)= \begin{cases}{\left[\frac{\gamma v^{\prime}\left(D_{t}\right)}{1-r_{t+1, i}^{d} \beta_{t}}\right]^{\eta} D_{t}} & , \text { if } r_{t+1, i}^{d} \geq 1 / \pi_{t+1} \\ 0 & , \text { else. }\end{cases}
$$

In the first case, deposit rates exceed the return on money, and banks can attract more funding, the higher the deposit rate $r_{t+1, i}^{d}$. The elasticity of substitution $\eta$ governs how elastic demand is with respect to deposit rates, as greater substitutability makes it easier for households to switch to competitors. Intuitively, the demand for deposits increases in the preference for liquidity services $\gamma$.

In the second case, money dominates deposits and demand drops to zero. Hence, nominal deposit rates are subject to a zero lower bound and real deposit rates subject to a " $1 / \pi_{t+1}$ lower bound".

\footnotetext{
${ }^{15}$ Note that due to log-utility the solution is always interior. $C_{t}$ can take negative values, which can be interpreted as working extra hours, as in Brunnermeier and Sannikov (2014).
} 


\subsection{The Bank's Problem}

In each period $t$, bank $i$ sets its gross deposit rate $r_{t+1, i}$, chooses its monitoring intensity $m_{t, i}$, and decides how much equity to contribute per unit of deposit, denoted $e_{t, i}$. An exogenous regulatory capital requirement mandates that $e_{t, i} \geq \bar{e}_{t}$. Section 6 derives the welfare-maximizing level of $\bar{e}_{t}$.

Each bank has access to a single project of variable scale $I_{t, i}^{b}$, interpreted as making loans to bank-dependent borrowers. Since $e_{t, i}$ is expressed as equity per unit of deposit, ${ }^{16}$ the total investment scale is

$$
I_{t, i}^{b}=\left(1+e_{t, i}\right) D_{t, i}\left(r_{t+1, i}^{d}\right)
$$

With probability $q_{t, i}=q\left(m_{t, i}\right)$, the project succeeds and produces one unit of physical capital per unit of investment that can be rented to the representative firm in the following period. Success probabilities are i.i.d. across banks, so there is no aggregate risk.

In case of failure, the project produces nothing and the bank is in default. Shareholders enjoy limited liability, but failing banks lose their license and cannot continue operating. Each failing bank is replaced by a new entrant, but the total number of bank licenses is limited by mass 1, such that the total number of banks is constant. Entry is profitable because banks earn monopolistic rents.

The project's success probability increases in the bank's monitoring intensity $m_{t, i} \geq 0$. In principle, $q\left(m_{t}\right)$ can be any function with $q^{\prime}\left(m_{t}\right) \geq 0$, that is bounded by $\lim _{m_{t} \rightarrow \infty} q\left(m_{t}\right) \leq$ 1 , and $\lim _{m_{t} \rightarrow 0} q\left(m_{t}\right) \geq 0$. For concreteness I use as functional form the CDF of the Standard Gaussian distribution, $q\left(m_{t}\right)=\Phi\left(m_{t}\right)$, which is well-behaved and bounded between 0 and

1. Monitoring has a quadratic cost

$$
c\left(m_{t}\right)=\frac{\psi_{2}}{2} m_{t}^{2}
$$

per unit of investment, creating a trade-off between risk and return. Both bank and fi-

\footnotetext{
${ }^{16}$ This convention results in convenient mathematical expressions.
} 
nancial market investments are risky. The following assumption ensures bank monitoring is efficient:

\section{Assumption 1.}

$$
\max _{m_{t}} \frac{q\left(m_{t}\right)}{1+c\left(m_{t}\right)} \geq \bar{q}
$$

Thus, banks fulfill two roles. On the liability side, they create liquid deposits that households value for their convenience yield. On the asset side, banks perform valuable monitoring activities that efficiently reduce the riskiness of loans. These benefits stand against operating costs of $\psi_{1}$ per unit of investment. This parameter represents a bank's overall non-interest expenses, such as maintaining a branch network and costs of complying with regulation.

Banks that do not fail in a given period pay a net dividend

$$
d i v_{t, i}=\underbrace{\left[r_{t}^{k}\left(1+e_{t-1, i}\right)-r_{t, i}^{d}\right] D_{t-1, i}}_{\text {net interest income }}-\underbrace{\left[e_{t, i}+\left(1+e_{t, i}\right)\left(\psi_{1}+c\left(m_{t, i}\right)\right)\right] D_{t, i}}_{\text {cost of new loans }},
$$

that consists of the bank's net interest income (defined as the net return on loans, after repaying depositors), net of monitoring and operating costs, as well as equity contributed to new loans. For new entrants, $d i v_{t, i}<0$ because these banks have no interest income from previous loans and must therefore raise equity externally. Failing banks pay zero dividends, as they are shut down.

A central element in the further analysis is the bank's franchise value $V_{t}$, which generally takes strictly positive values due to the market power of banks. ${ }^{17}$ It is convenient to define $V_{t}$ as the value of a bank's current and future loans:

$$
V_{t}^{=} \max _{m_{t, i}, e_{t, i}, r_{t+1, i}^{d}} \Pi_{t, t+1}^{b} D_{t, i}\left(r_{t+1, i}^{d}\right)+q\left(m_{t, i}\right) \beta_{t} \mathbb{E}_{t} V_{t+1}
$$

where $\Pi_{t, t+1}^{b}$ denotes discounted expected profits per unit of deposits,

$$
\Pi_{t, t+1}^{b} \equiv q\left(m_{t, i}\right) \beta_{t}\left[r_{t+1}^{k}\left(1+e_{t, i}\right)-r_{t+1, i}^{d}\right]-\left[e_{t, i}+\left(1+e_{t, i}\right)\left(\psi_{1}+c\left(m_{t, i}\right)\right],\right.
$$

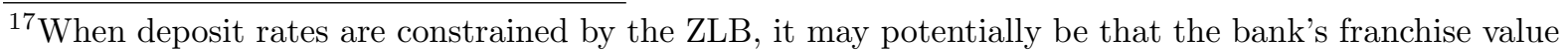
turns negative. I do not study this case and focus on equilibria with $V_{t} \geq 0$
} 
and the problem is subject to the following constraints:

$$
\begin{aligned}
D_{t, i}\left(r_{t+1, i}^{d}\right) & = \begin{cases}{\left[\frac{\gamma v^{\prime}\left(D_{t}\right)}{1-r_{t+1, i}^{d} \beta_{t}}\right]^{\eta} D_{t}} & , \text { if } r_{t+1, i}^{d} \geq 1 / \pi_{t+1} \\
0 & , \text { else. }\end{cases} \\
e_{t, i} \geq \bar{e}_{t} &
\end{aligned}
$$

Equation (9) is the demand for deposit variety $i$ derived from the household problem (see Eq. 6), and (10) is the regulatory capital requirement.

Optimal monitoring and deposit rates. The first order condition with respect to $m_{t}$ characterizes a bank's optimal monitoring decision:

$$
c^{\prime}\left(m_{t, i}\right)\left(1+e_{t, i}\right) D_{t, i}=q^{\prime}\left(m_{t, i}\right) \beta_{t}\left(\left[\left(1+e_{t, i}\right) r_{t+1}^{k}-r_{t+1, i}^{d}\right] D_{t, i}+\mathbb{E}_{t} V_{t+1}\right)
$$

Intuitively, banks equate the marginal cost of monitoring on the left-hand side to the marginal benefit on the right-hand side. The benefit from monitoring is a reduced failure probability. Thus, monitoring is more valuable when a bank's net interest income is higher and its continuation value $\mathbb{E}_{t} V_{t+1}$ is higher.

Due to the discontinuity in deposit demand, the deposit rate is either at an interior solution or at the corner $r_{t+1, i}^{d}=1 / \pi_{t+1}$ if the ZLB binds. The first order condition w.r.t. the deposit rate yields the following interior solution:

$$
r_{t+1}^{d, i n t}=\frac{\eta}{(\eta-1)}\left(r_{t+1}^{k}\left(1+e_{t, i}\right)-\frac{1}{\beta_{t}}\left[\frac{1}{\eta}+\frac{e_{t, i}+\left(1+e_{t, i}\right)\left(\psi_{1}+c\left(m_{t, i}\right)\right)}{q\left(m_{t}\right)}\right]\right) .
$$

Thus, the deposit rate is given by

$$
r_{t+1, i}^{d}=\max \left\{r_{t+1}^{d, i n t}, \frac{1}{\pi_{t+1}}\right\}
$$

In the first case in the max-function, banks set the deposit rate at an interior solution $r_{t+1}^{d, i n t}$. Deposit rates are below the return on loans, which is equal to the rental rate on capital $r_{t+1}^{k}$. Banks pass on their costs and charge a mark-up, which depends on the 
elasticity of substitution between deposits $\eta$. A higher level of $\eta$ implies less market power and hence higher deposit rates.

If $r_{t+1}^{d, i n t}$ is smaller than $1 / \pi_{t+1}$, nominal deposit rates would be negative at the interior solution. In this case, the ZLB binds and the second case in the max-function applies.

Costly bank equity. The FOC w.r.t. $e_{t, i}$ is given by

$$
\frac{\partial V_{t}^{b}}{\partial e_{t, i}}=q\left(m_{t, i}\right) \beta_{t} r_{t+1}^{k}-\left(1+c\left(m_{t, i}\right)+\psi_{1}\right)
$$

The first order condition reflects the net return from a marginal unit of bank equity. Keeping everything else fixed, bank equity generates an expected discounted gross return of $q\left(m_{t, i}\right) \beta_{t} r_{t+1}^{k}$ at a cost of 1 plus monitoring and operating expenses. By Assumption 1, bank monitoring is efficient, so the net return from monitoring is generally positive. ${ }^{18}$ This benefit is weighed against the operating cost $\psi_{1}$. If $\psi_{1}>q\left(m_{t, i}\right) \beta_{t} r_{t+1}^{k}-\left(1+c\left(m_{t, i}\right)\right)$, bank equity is expensive in the sense that a marginal unit of equity invested in banks earns a lower net return than a marginal unit invested directly in the financial market. In this case, the FOC w.r.t. $e_{t, i}$ is negative, and banks choose to raise the minimum level of equity consistent with the regulatory constraint, $e_{t, i}=\bar{e}_{t}$.

Definition 1. Bank equity is expensive if $\psi_{1}>q\left(m_{t, i}\right) \beta_{t} r_{t+1}^{k}-\left(1+c\left(m_{t, i}\right)\right)$.

Lemma 1. If bank equity is expensive, the regulatory capital requirement binds so that $e_{t, i}=\bar{e}_{t}$

Lemma 2 follows immediately from the observations that if bank equity is expensive, then $\frac{\partial V_{t}^{b}}{\partial e_{t, i}}<0$. Analytical results in Section 4.3 restrict attention to the empirically plausible case of a binding capital requirement. ${ }^{19}$ Any numerical solutions generally

\footnotetext{
$\overline{{ }^{18} \text { By the household's Euler Equation }(4),} \beta_{t} r_{t+1}^{k}=1 / \bar{q}$. Thus, Assumption 1 implies that at the optimal monitoring level $m^{*}, q\left(m^{*}\right) \beta_{t} r_{t+1}^{k}-\left(1+c\left(m^{*}\right)\right)>0$, where $m^{*}$ is defined as described in Assumption 1.

${ }^{19}$ In reality, banks have small buffers above regulatory requirements to avoid breaking them. In the model, this corresponds to being exactly at the constraint because, unlike in the real world, equity can be raised instantaneously without frictions.
} 
allow both cases to occur, though the capital requirement also turns out to be binding in the calibration described in Section 5.1.

Two things are worth noting. First, a marginal unit of equity being costly does not mean the average return on bank equity is lower than in the financial market. In fact, banks earn superior returns due to their market power, so households happily own bank stock. ${ }^{20}$ The subtle difference is between raising new equity and holding existing stocks. While outstanding stocks are valuable, bank management would not voluntarily raise new equity funding.

Second, while a marginal unit of bank equity is privately costly for shareholders, it may still be socially beneficial. Higher levels of bank equity can curb excessive risk-taking, the downside of which is not fully internalized by shareholders due to the presence of deposit insurance. As shown in Section 5, welfare-maximizing capital requirements are strictly positive and exceed $10 \%$ in a calibration to U.S. data.

\subsection{Government}

To close the model, the government issues real money balances $M_{t}$ to satisfy household demand for cash and raises real lump-sum taxes $T_{t}$ to finance the deposit insurance scheme. Thus, the government runs a balanced budget, and bonds are in zero net supply. In the remainder, I focus on symmetric equilibria, such that, in each period, a fraction $\left(1-q\left(m_{t-1}\right)\right)$ of banks fail. Thus, the government needs to raise taxes of

$$
T_{t}=\left(1-q\left(m_{t-1}\right)\right) r_{t}^{d} D_{t-1}+\frac{M_{t-1}}{\pi_{t}}-M_{t}
$$

Note that the equilibrium demand for money is 0 as long as nominal deposit rates are not negative. Finally, I assume that the central bank implements a series of nominal rates $i_{t}^{b}$ to achieve a fixed inflation target $\pi$. This approach allows focusing the analysis on real allocations, while treating the inflation target as exogenous, and with money serving

\footnotetext{
${ }^{20}$ If bank stocks were traded, the superior return of banks would be reflected in high stock prices.
} 
the role of imposing a lower bound on deposit rates. It also allows to study exogenous variations in the inflation target, which are a key comparative static of interest in the analysis in Section 4.

\subsection{Equilibrium and Model Solution}

The only state variables of the model are the capital stock $K_{t}$ and the realization of the discount factor $\beta_{t}$. Both are known at the beginning of the period, and decisions are made subsequently. In the following equilibrium definition and the remainder of the paper I focus on symmetric equilibria, in which all banks choose the same deposit rate and monitoring intensity.

Definition. Given capital requirements $\left\{\bar{e}_{t}\right\}_{t=0}^{t=\infty}$, an inflation target $\pi$, transition probabilities $P_{s s^{\prime}}$, an initial state $s_{0} \in\{H, L\}$, initial capital stock $K_{0}$, and initial price level, a symmetric competitive equilibrium is a set of prices $\left\{r_{t}^{b}, r_{t, i}^{d}, r_{t}^{k}, w_{t}\right\}_{t=0}^{t=\infty}$, and allocations $\left\{K_{t+1}, I_{t}^{m}, I_{t}^{b}, C_{t}, \quad D_{t}, N_{t}, M_{t}, e_{t}, m_{t}, T_{t}\right\}_{t=0}^{t=\infty}$, such that

(a) Given an initial capital stock $K_{0}$ and prices $\left\{r_{t}^{k}, w_{t}\right\}_{t=0}^{t=\infty}$, firms maximize profits.

(b) Given prices $\left\{r_{t}^{b}, w_{t}, r_{t, i}^{d}, r_{t}^{k}\right\}_{t=0}^{t=\infty}$, households maximize lifetime utility solving (3).

(c) Given prices $\left\{r_{t}^{k}\right\}_{t=0}^{t=\infty}$, banks maximize their franchise value solving (8).

(d) The government runs a balanced budget and raises taxes (14).

(e) Market clearing is satisfied at any time $t \geq 0$

- aggregate resource constraint:

$$
C_{t}+I_{t}^{m}+I_{t}^{b}\left(1+c\left(m_{t}\right)+\psi_{1}\right)=F\left(K_{t}\right),
$$

- capital:

$$
K_{t}=\bar{q} I_{t-1}^{m}+q\left(m_{t}\right) I_{t-1}^{b}
$$

- labor:

$$
N_{t}=1
$$


The equations characterizing the equilibrium are summarized in Appendix A.1. The forward-looking nature of the bank's problem and the occasionally binding ZLB constraint potentially complicate solving the full dynamic model. However, owing to the simple stochastic structure and linear utility function, the equilibrium allocations relevant for the bank's forward-looking problem $\left(r_{t}^{k}, e_{t}\right.$ and $\left.D_{t}\right)$ depend on the current state only, i.e. they are memory-less and independent of the time period $t$. This property simplifies solving the forward-looking bank problem, as it allows expressing the expected franchise value as

$$
\mathbb{E}_{s} V_{t+1}=P_{s s^{\prime}} V_{s}+\left(1-P_{s s^{\prime}}\right) V_{s^{\prime}}
$$

Therefore, the bank's value function can be solved as a simple system of non-linear equations, allowing to solve the model globally easily. For ease of notation, I sometimes denote the value of a memory-less variable $x_{t}$ in state $s$ simply as $x_{s}$ and the expectations given state $s$ as $\mathbb{E}_{s} x_{t+1} \equiv \mathbb{E}_{t}\left[x_{t+1} \mid s\right]$.

\subsection{Discussion of Inefficiencies}

There are several frictions in the model. First, the presence of deposit insurance implies that bank risk-taking is mis-priced. Second, banks have market power, so deposit rates are below their competitive level. Third, the presence of money means nominal deposit rates cannot go negative.

Appendix A.2 derives the first best allocation and shows these distortions imply that, in the competitive equilibrium, bank risk-taking and liquidity provision are at inefficient levels. Deposit insurance induces banks to take more risk than is socially optimal. This effect is counter-weighed by market power, which increases franchise values and makes it more valuable for banks to survive. At the same time, market power implies that banks provide inefficiently little liquidity.

Deposit insurance is introduced as an exogenous feature of the model economy. It could 
be motivated endogenously by assuming that only fully safe assets can serve as money, as in Stein (2012). Alternatively, Appendix A.4 shows a distortion in risk-taking could also be introduced by assuming that monitoring is not contractible, and banks choose monitoring sequentially after raising funding. What matters for this paper is that there is some distortion in risk-taking. The main text focuses on deposit insurance, which is a realistic feature that allows to introduce the distortion parsimoniously.

\section{Static Model}

This section uses a tractable, static version of the model with two dates, $t$ and $t+1$, to derive some key results analytically. The goal is to highlight clearly how interest rates affect risk-taking and capital regulation. Sections 5 and 6 use the full dynamic model.

Throughout this section, I make the following parameter restriction that ensures the regulatory capital requirement binds (see Lemma 1):

Assumption 2. $\psi_{1}>\frac{q\left(m_{t}\right)}{\bar{q}}-\left(1+c\left(m_{t}\right)\right), \forall m_{t} \geq 0$

\subsection{Disentangling Risk-Taking Incentives}

In the static version of the model, $\mathbb{E}_{t}\left[V_{t+1}\right]=0$, so that the first order condition w.r.t. monitoring (11) can be simplified as

$$
\frac{c^{\prime}\left(m_{t}\right)}{q^{\prime}\left(m_{t}\right)}=\underbrace{\beta_{t}}_{\text {Discounting }}(\underbrace{r_{t+1}^{k} \bar{e}_{t}}_{\text {Skin in the game }}+\underbrace{\left(r_{t+1}^{k}-r_{t+1}^{d}\right)}_{\text {Net interest margin }}) .
$$

Equation (15) parsimoniously characterizes equilibrium monitoring. The left-hand side of Eq. (15) is increasing in $m_{t}{ }^{21}$ so equilibrium monitoring increases in the right-hand side of Eq. (15). This means the right-hand side captures the relevant channels driving monitoring incentives.

\footnotetext{
${ }^{21}$ This is easy to verify because $c^{\prime}\left(m_{t}\right)=\psi_{2}$ and $q^{\prime}\left(m_{t}\right)$ is the PDF of the Standard Gaussian Distribution and hence decreases for any $m_{t} \geq 0$.
} 
First, if banks have more of their own funds at stake, they monitor more intensely due to a standard skin in the game effect. Second, banks monitor more if they earn higher interest margins because banks stand to lose more upon failure, the higher their net interest income. This latter channel can be described as a franchise value effect because, in a static setting, a bank's franchise value is captured by its net interest income from current operations (in a dynamic setting, the bank's continuation value $\mathbb{E}_{t} V_{t+1}$ also matters, see Section 5). Finally, discounting matters for the strength of these two effects because both channels work through income generated in the future, while the cost of monitoring is incurred today.

\subsection{Low Rates and Risk-Taking}

This section analyzes how the level of real and nominal interest rates affect equilibrium monitoring. Real interest rates are pinned down by the households' discount factor $\beta_{t}$, via the Euler equation (4):

$$
r_{t+1}^{b}=\frac{1}{\beta_{t}}
$$

Nominal interest rates are linked to real rates via the Fisher equation

$$
i_{t+1}^{b}=r_{t+1}^{b} \pi_{t+1}
$$

A first experiment considers changes in real rates induced by changes in $\beta_{t}$, keeping inflation fixed. A second experiment analyzes changes in nominal interest rates through inflation, keeping real rates fixed.

For the further analysis, it is useful to clarify under what conditions the zero lower bound binds. Banks set their deposit rate according to the first-order condition (12). This is at an interior solution if the return on capital is sufficiently high and at the corner solution $r_{t+1}^{d}=1 / \pi_{t+1}$ if the ZLB binds.

Lemma 2. The $Z L B$ is slack (i.e. banks set an interior deposit rate $r_{t+1}^{d} \geq 1 / \pi_{t+1}$,) if 
and only if

$$
\beta_{t} \leq \beta_{t}^{Z L B}
$$

where $\beta_{t}^{Z L B}$ is implicitly defined by

$$
\beta_{t}^{Z L B}=\pi_{t+1}\left(\frac{\eta / \bar{q}-1}{\eta-1}-\frac{\eta}{\eta-1} \frac{\left(1-q\left(m_{t}^{*}\right) / \bar{q}\right) \bar{e}_{t}+\left(1+\bar{e}_{t}\right) c\left(m_{t}^{*}\right)}{q\left(m_{t}^{*}\right)}\right)
$$

and $m_{t}^{*}$ denotes the equilibrium level of monitoring.

Lemma 2 defines a threshold $\beta_{t}^{Z L B}$, above which the ZLB binds. If $\beta_{t}$ is high, real interest rates are low, and banks set deposit rates closer to zero.

\subsubsection{Changes in Real Interest Rates}

How changes in $\beta_{t}$ affect monitoring incentives depends on whether the right-hand side of Eq. (15) increases or decreases in $\beta_{t}$. The direct effect of $\beta_{t}$ is an increase in the righthand side. Less discounting increases the present value of profits at $t+1$, and via this discounting channel, lower rates result in higher equilibrium monitoring.

However, looking at the discounting channel in isolation ignores the equilibrium responses of $r_{t+1}^{k}$ and $r_{t+1}^{d}$. To the extent that lower interest rates may harm the interest margin of banks, lower rates may result in less monitoring via a margin channel that undermines franchise value.

Which channel dominates? Plugging the Euler equation (4) into Eq. (15) allows to express it as

$$
\frac{c^{\prime}\left(m_{t}\right)}{q^{\prime}\left(m_{t}\right)}=\frac{r_{t+1}^{k}}{r_{t+1}^{b}}\left(1+\bar{e}_{t}\right)-\frac{r_{t+1}^{d}}{r_{t+1}^{b}}
$$

The no-arbitrage condition (5) further requires that the ratio between the return on capital and bonds is constant at $\frac{r_{t+1}^{k}}{r_{t+1}^{b}}=\frac{1}{\bar{q}}$. Thus, in the static version of the model the equilibrium response of monitoring depends solely on the ratio $\frac{r_{t+1}^{d}}{r_{t+1}^{b}} \cdot{ }^{22}$ Intuitively, if in

\footnotetext{
${ }^{22}$ In the dynamic model, the comparative statics are more complicated due to the endogenous continuation value. Section 5 shows that the numerical results from the dynamic model are consistent with the static model.
} 
response to an increase in $\beta_{t}$ equilibrium deposit rates fall more than bond rates, interest margins shrink, lowering profitability and thus increasing risk-taking incentives. Using the bank's FOC for deposit rates (12), this ratio can be expressed as

$$
\frac{r_{t+1}^{d}}{r_{t+1}^{b}}= \begin{cases}\frac{\eta / \bar{q}-1}{\eta-1}-\frac{\eta}{\eta-1} \frac{\left(1-q\left(m_{t, i}\right) / \bar{q}\right) \bar{e}_{t}+\left(1+\bar{e}_{t}\right)\left(\psi_{1}+c\left(m_{t, i}\right)\right)}{q\left(m_{t, i}\right)} & , \text { if } \beta_{t} \leq \beta_{t}^{Z L B} \\ \beta_{t} / \pi_{t+1} & \text { else. }\end{cases}
$$

In the first case $\left(\beta_{t} \leq \beta_{t}^{Z L B}\right)$, the ZLB is slack and deposit rates are at an interior solution. In this case, banks can largely pass on lower interest rates to depositors, so the ratio $\frac{r_{t+1}^{d}}{r_{t+1}^{b}}$ is not a function of $\beta_{t}$. The discounting and margin channels exactly offset each other, and the level of real interest rates does not affect equilibrium monitoring.

In the second case, the ZLB binds and the real deposit rate is bounded by $1 / \pi_{t+1}$. Thus, any decrease in interest rates eats one-for-one into interest margins, so the ratio $\frac{r_{t+1}^{d}}{r_{t+1}^{b}}$ increases in $\beta_{t}$. As a result, at the ZLB monitoring decreases in response to an increase in $\beta_{t}$, as real rates fall. The following proposition summarizes:

Proposition 1. An increase in $\beta_{t}$ reduces real interest rates $r_{t+1}^{b}$. Lower real rates result in less monitoring in equilibrium if the ZLB binds:

$$
\begin{aligned}
& \frac{d m_{t}^{*}}{d \beta_{t}}=0, \text { if } \beta_{t} \leq \beta_{t}^{Z L B}, \\
& \frac{d m_{t}^{*}}{d \beta_{t}} \leq 0, \text { else. }
\end{aligned}
$$

The mechanism closely mirrors evidence in Heider et al. (2019). In a diff-in-diff setting, the authors show that negative policy rates in the Eurozone have eaten relatively more into the interest margin of banks with more deposit relative to wholesale funding. Consistent with the notion that tight margins spur risk-taking, these banks are shown to increase their lending to riskier borrowers as interbank rates fall below zero. 


\subsubsection{Inflation and Nominal Interest Rates}

Proposition 1 considers the effect of changes in real interest rates induced by changes in discount factors. Next, turn to changes in nominal rates induced by higher inflation. By the Fisher equation, for a given level of real interest rates, higher inflation results in higher nominal interest rates. This can have a positive effect on monitoring incentives for two reasons. First, an increase in $\pi_{t+1}$ pushes up the threshold $\beta_{t}^{Z L B}$, above which the ZLB binds. Intuitively, for a given level of real rates, the ZLB is less likely to be binding if inflation and thus nominal rates are higher. Second, conditional on the ZLB binding, higher nominal rates alleviate the pressure on bank interest margins, so the ratio $\frac{r_{t+1}^{d}}{r_{t+1}^{b}}$ falls, see Eq. (18).

Proposition 2. A higher level of inflation increases the threshold $\beta_{t}^{Z L B}$ above which the ZLB binds (as defined in Lemma 2):

$$
\frac{\partial \beta_{t}^{Z L B}}{\partial \pi_{t+1}} \geq 0 .
$$

If the ZLB binds, an increase in inflation increases monitoring incentives:

$$
\begin{aligned}
& \frac{d m_{t}^{*}}{d \pi_{t+1}}=0, \text { if } \beta_{t} \leq \beta_{t}^{Z L B}, \\
& \frac{d m_{t}^{*}}{d \pi_{t+1}} \geq 0, \text { else. }
\end{aligned}
$$

\subsection{The Effectiveness of Capital Regulation at the Zero Lower Bound}

The previous analysis shows how the level of real and nominal rates affect monitoring incentives. A key regulatory tool to curb risk-taking is capital regulation. This section shows that this tool becomes less effective when the ZLB binds, i.e., exactly during times when risk-taking incentives are heightened.

From Eq. (15), an increase in capital requirements induces banks to monitor more intensely. Banks stand to lose more in case of failure when putting more of their own 
funds at stake - a standard skin-in-the-game effect. However, this analysis is partial and ignores equilibrium effects. As evident from Eq. (17), equilibrium monitoring depends not only on the level of $\bar{e}_{t}$ directly, but also indirectly via the ratio $\frac{r_{t+1}^{d}}{r_{t+1}^{b}}$.

Using Eq. (18), it is easy to verify that away from the ZLB, $\frac{r_{t+1}^{d}}{r_{t+1}^{b}}$ decreases in $\bar{e}_{t}$ if equity is expensive:

$$
\frac{\partial\left(r_{t+1}^{d} / r_{t+1}^{b}\right)}{\partial \bar{e}_{t}}=-\frac{\eta}{(\eta-1)} \frac{1}{q\left(m_{t}\right)}\left(1+\psi_{1}+c\left(m_{t}\right)-\frac{q\left(m_{t}\right)}{\bar{q}}\right) .
$$

This derivative is negative if the term in brackets is positive, which is true as long as equity is expensive (see Lemma 1). Intuitively, if banks find equity expensive, they pass on some of that cost to depositors by lowering deposit rates.

In contrast, if the ZLB binds, the ratio $\frac{r_{t+1}^{d}}{r_{t+1}^{b}}$ is not a function of $\bar{e}_{t}$ because, in this case, deposit rates are already at a corner solution. In this case, banks can no longer respond to tighter capital requirements by lowering deposit rates. As a result, the effectiveness of capital requirements in curbing risk-taking incentives depends on whether the ZLB binds:

Proposition 3. Higher capital requirements increase equilibrium monitoring:

$$
\frac{d m_{t}^{*}}{d \bar{e}_{t}} \geq 0
$$

The effect of capital requirements on equilibrium monitoring is weakened if the ZLB binds.

That is, considering two values $\beta_{t}^{\prime}<\beta_{t}^{Z L B}$ and $\beta_{t}^{\prime \prime} \geq \beta_{t}^{Z L B}$ :

$$
\left.\frac{d m_{t}^{*}}{d \bar{e}_{t}}\right|_{\beta_{t}^{\prime}} \geq\left.\frac{d m_{t}^{*}}{d \bar{e}_{t}}\right|_{\beta_{t}^{\prime \prime}} .
$$

The proof is in Appendix A.5. By the direct skin-in-the-game effect, tighter capital requirements increase monitoring incentives as banks have more of their own funds at stake. However, the overall response also depends on how a bank's franchise value responds to tighter regulation. If banks can pass on the cost of equity to depositors by lowering deposit rates, they can avoid a negative impact on profitability. This mechanism 
is not present at the ZLB, where deposit rates are at a corner solution and cannot be adjusted. For this reason, capital requirements are less effective in increasing monitoring incentives when the ZLB binds.

The role of market power. How strongly banks can adjust deposit rates in response to tighter capital requirements depends on their market power, which is governed by the elasticity of substitution between deposits of different banks $\eta$. From Eq. (19) it is clear that deposit rates adjust less to an increase in $\bar{e}_{t}$, the higher $\eta$. In the case of perfect competition, $\eta \rightarrow \infty$, and so $\eta /(\eta-1) \rightarrow 1$. The ratio $\eta /(\eta-1)$ increases as banks have more market power. In the extreme case of full monopoly power, $\eta \rightarrow 1$, banks always set deposit rates equal to the reservation price of depositors, $r_{t+1}^{b}=1 / \pi_{t+1}$. These considerations give rise to the following corollary to Proposition 3:

Corollary 1. As long as the $Z L B$ is slack $\left(\beta_{t}<\beta_{t}^{Z L B}\right)$, capital requirements have a stronger effect on equilibrium monitoring, the more market power banks have, (the lower

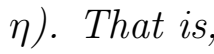

$$
\frac{\left(d m_{t}^{*} / d \bar{e}_{t}\right)}{d \eta} \leq 0
$$

\subsection{Discussion of the Mechanism}

The key to obtaining the result that capital requirements are less effective at the ZLB is that capital is privately costly for banks and that banks can pass on some of this cost to depositors. That equilibrium prices are a function of marginal costs is not a unique feature of the monopolistic competition setup used here. What is important is that banks do not have full monopoly power because, otherwise, they could always put depositors on their reservation price $r_{t+1}^{b}=1 / \pi_{t+1}$. Appendix A.3 shows the results are robust to using a circular road model of competition as in Salop (1979).

Using a Monti-Klein model of bank competition, Hellmann et al. (2000) show that 
higher capital requirements may more generally undermine bank franchise value. This is in contrast to the result in Proposition 3, where lowering deposit rates can undo the negative impact on profitability as long as the ZLB remains slack. ${ }^{23}$

Hence, whether capital requirements do or do not reduce franchise value away from the ZLB may depend on modeling choices. The main point and general result here is that at the ZLB higher capital requirements disproportionately affect franchise values. Clearly, the ZLB eliminates one margin of adjustment, such that higher capital requirements must inevitably have a more negative effect on bank profitability when the ZLB binds.

Market power on the lending side. While banks have market power in deposit markets, they are price takers on the lending side. In the real world, banks have some market power over borrowers that cannot easily substitute bank funding for other sources of finance, such as small businesses and households. Market power on the lending side could be an additional margin of adjustment and relieve some of the pressure on profitability at the ZLB. Instead, the result would be a misallocation of finance between bank-dependent and bank-independent borrowers (e.g., see Wang, 2018). However, at the margin, some borrowers can substitute for other sources of finance. While market power may support margins to some extent, it would thus not fully overcome the problem.

Competition-stability framework. Contrary to this paper, other contributions in the literature show that higher bank competition may actually decrease risk-taking incentives.

\footnotetext{
${ }^{23}$ Modeling differences to Hellmann et al. (2000) are the monopolistic competition setup, and the general equilibrium approach taken in this paper. In Hellmann et al. (2000) equity is priced by the opportunity cost of funds of bank owners, and banks face an exogenous demand for deposits as well as a choice between two investment opportunities with exogenously given returns. Here, households price the required return on equity and assets (via financial market investments), and the demand for deposits is also derived from household optimization. This equilibrium approach is useful when studying the effect of changing interest rates, as shifts in the household's discount factor affect the entire spectrum of required returns and interest rates.
} 
For example, Boyd and De Nicolo (2005) place the risk shifting problem at the firm rather than the bank level. By charging lower lending rates, a more competitive banking sector then increases the "margin" of firms (between asset returns and borrowing rates), thereby increasing firm franchise value and lowering risk-taking. Interestingly, the main result in this section is robust, whether the moral hazard problem is placed with banks or with firms.

To see this, consider a variation of the model, in which the risk-taking decision is done by firms that earn a margin between final asset returns and lending rates, which in turn depend on the competitiveness of the banking sector. When the ZLB constrains deposit rates, falling returns inevitably reduce the margin between final asset returns and deposit rates. Some of that squeeze in margins would have to be borne by firms, inducing them to take more risk.

\section{Dynamic Model}

The goal of this section is to calibrate the model's parameters, show robustness of the analytical results in the dynamic model, and highlight the role of expectations about the future interest rate path. Section 6 then uses the dynamic model to analyze what the positive results mean for optimal policy, if the ZLB binds occasionally.

In the dynamic model, the household's discount factor moves stochastically according to a two-state Markov process, as outlined in Section 3.2. This generates variation in real interest rates over time, so that the economy is either in a high- or low-rate state.

\subsection{Calibration}

Parameters are calibrated to U.S. data. The inflation rate is set in line with the Fed's target of $2 \%$, to $\pi=1.02$. The high-rate state represents times with safe, short-term 
rates away from the ZLB, such as the period from the 1990s until the financial crisis in 2008. Accordingly, I set $\beta_{H}=0.975$, which results in a nominal bond yield of $4.6 \%$ $\left(=\pi / \beta_{H}-1\right)$, in line with the average yield on treasuries over 1996-2008. The level of rates in the low-rate state is one of the main comparative statics of interest. In the baseline calibration, $\beta_{L}=1.005$, to target an average treasury yield over 2009-2015 of around $1.5 \%\left(=\pi / \beta_{L}-1\right)$. The success probability of financial market investments is set to $\bar{q}=0.985$, in line with an average corporate bond spread of around $1.5 \%$ from 1996-2017, according to FRED Data. This number is also in line with average corporate bond default rates reported in S\&P's 2018 Annual Global Corporate Default and Rating Transition Study.

I set $\alpha=0.33$, in line with a third of income going to capital. Capital requirements are set s.t. $\bar{e}_{t} /\left(1+\bar{e}_{t}\right)=0.085$, equal to the minimum requirement of the Tier 1 capital ratio in the Basel III framework.

The cost parameters $\psi_{1}$ and $\psi_{2}$ are set to reflect the aggregate non-interest expenses over assets of U.S. banks, which averages slightly below 3\% over the period 1996-2017 according to the FDIC's Historical Bank Data. The parameter $\psi_{2}$ reflects the cost of monitoring and hence governs a bank's failure probability $\left(1-q\left(m_{t}\right)\right)$. Hence, I also target the average annual proportion of banks failing in the U.S. of around $0.76 \%$ (computed by Davydiuk (2017) using the Failed Bank List issued by the FDIC). This yields $\psi_{1}=0.024$ and $\psi_{2}=0.0015$.

The elasticity of substitution $\eta$ governs bank market power and hence the interest margin $r_{t}^{k}-r_{t}^{d}$. I use the FDIC's Historical Bank Data to proxy deposit rates as the deposit interest expense per unit of deposits. Similarly, the interest income rate is the ratio of interest income over total assets, and the interest margin is the difference between interest income and expense ratio. The average interest margin over the period 1996-2008 is $3.3 \%$, consistent with a value of $\eta=8$. 
Given the calibration of bank parameters, I set $\gamma$ to target the ratio of aggregate deposit liabilities of U.S. chartered institutions to non-financial corporate debt instruments, using data from the Flow of Funds. Setting $\gamma=0.0007$ results in a ratio of $D_{t} /\left(D_{t}+I_{t}^{m}\right)=0.2$, consistent with Flow of Funds data.

Finally, in the baseline calibration the transition probabilities are set to $P_{H H}=0.9$ and $P_{L L}=0.8$. This implies an expected duration of 10 years spent in the high-rate state and 5 years in the low-rate state. For comparison, the Federal Funds Rate target range was at $0 \%$ for seven years, from December 2008 to December 2015. All parameter values are summarized in Table 1 in Appendix A.6.

In this calibration, the capital requirement binds, and the ZLB is slack in the high-rate state but binding in the low-rate state.

\subsection{Risk-Taking at the Zero Lower Bound}

Figure 4 expands upon the results in Proposition 1 by considering a change in $\beta_{L}$ along the entire dynamic equilibrium path, rather than a marginal change in $\beta_{t}$. The left panel of Figure 4 plots the equilibrium failure probability $1-q\left(m_{t}\right)$ against the discount factor $\beta_{L}$. The dotted horizontal line marks the threshold $\beta_{t}^{Z L B}$, to the right of which the ZLB binds.

The discounting channel described in Section 4.2 dominates as long as the ZLB is slack $\left(\beta_{L} \leq \beta_{L}^{Z L B}\right)$. Banks take less risk as $\beta_{L}$ increases, though the magnitude of the effect is quite modest. Failure probabilities fall by a few basis points as the nominal return on capital $\left(i_{t}^{k}=r_{t}^{k} \pi_{t}\right.$ ) falls from above $4 \%$ (at $\beta=0.9925$ ) to around $3.3 \%$ (at $\left.\beta=\beta_{L}^{Z L B}=1.002\right)$. Thus, low real rates have little effect on risk-taking as long as the ZLB is slack and banks can pass on lower rates to depositors, in line with the analytical result in Proposition 1.

In contrast, when the ZLB binds, the margin channel dominates and falling interest 

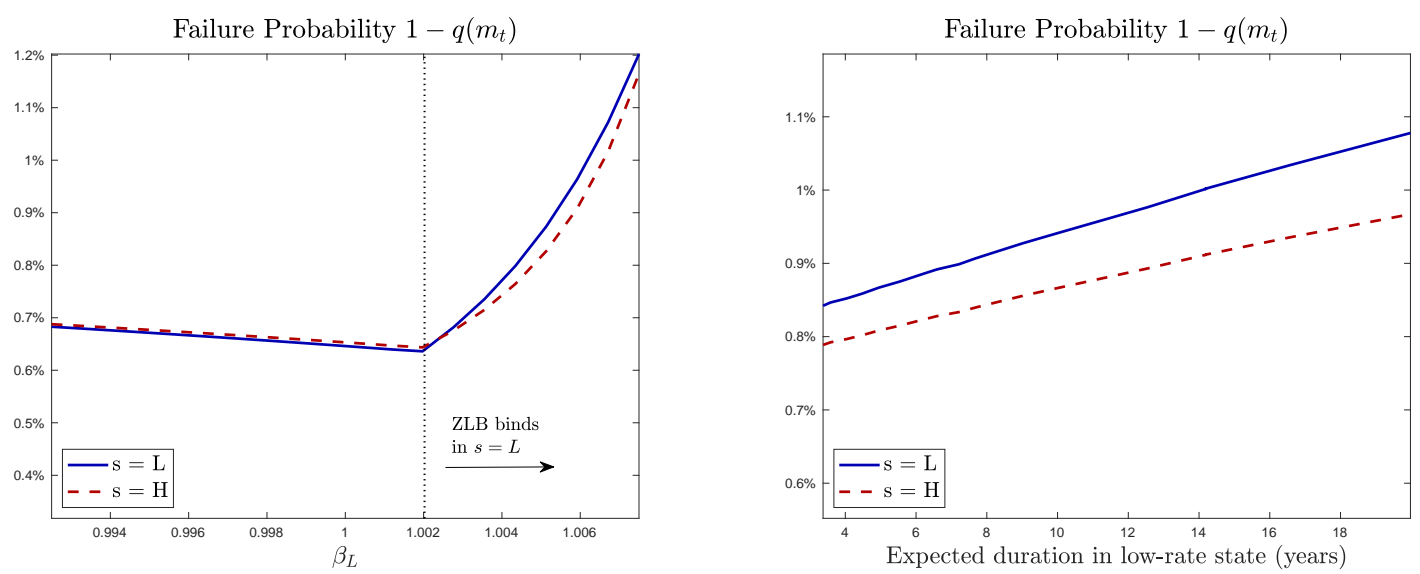

Figure 4: The left panel plots equilibrium risk-taking in the low- and high-rate states against the discount factor in the low-rate state $\beta_{L}$. The right panel plots risk-taking against the expected duration of remaining in the low rate state, governed by the parameter $P_{L L}$. Parameters are calibrated as described in Section 5.1 .

rates result in a sizable increase in risk-taking. The annual probability of failure almost doubles from around $0.65 \%$ to above $1.1 \%$, as the return on capital falls from $3.3 \%$ (at $\left.\beta_{L}=\beta_{L}^{Z L B}\right)$ to $2.75 \%\left(\right.$ at $\left.\beta_{L}=1.0075\right)$

Figure 4 also reveals that a binding ZLB in the low-rate state affects risk-taking in the high-rate state, even though the ZLB is slack in the high-rate state (see the dashed red line). Incentives are affected not only by current profits, but also by expectations about profitability going forward. This result highlights the relevance of considering dynamics.

Because expectations about future profitability affect franchise value, it matters how long the economy is expected to remain at the ZLB. This can be seen in the right panel of Figure 4. The comparative static exercise here keeps $\beta_{L}$ fixed at its baseline value (where the ZLB binds) and considers changes in $P_{L L}$, the likelihood of remaining in the low-rate state. In the figure, $P_{L L}$ varies between 0.7 and 0.95 , which corresponds to an expected duration of under 4 to up to 20 years in the low-rate state. The figure reveals that failure probabilities increase by approximately $0.01 \%$ for every additional expected year the economy remains at the ZLB.

This experiment shows that a zero interest environment may be particularly problem- 
atic when rates are expected to remain low for long. The lower end of the Fed Funds target range hit $0 \%$ in December 2008, where it remained for seven years until the Fed started lifting rates in December 2015. In the Eurozone and Japan, rates are expected to remain near-zero for an even longer time. The ECB lowered its deposit facility rate close to zero by the beginning of 2009 and even moved them into negative territory in 2016 .

Even with rates in the U.S. currently above zero, the overall level of interest rates is expected to remain low. This increases the likelihood of frequently hitting zero through the monetary policy loosening cycle. The results here show that even when banks are not currently constrained by the ZLB, the prospect of a binding ZLB in the future can affect incentives today.

\subsection{The Effectiveness of Capital Requirements at the ZLB}

Figure 5 illustrates how capital regulation affects bank franchise values and risk-taking, relating to the results from Proposition 3 in a dynamic context. The left panel plots the equilibrium franchise value in the low-rate state $V_{L}$, against the capital requirement $\bar{e}_{L}$ (keeping $\bar{e}_{H}$ fixed), for different levels of $\beta_{L}$ and likelihood of remaining in the low-rate state $P_{L L}$.

With $\beta_{L}=0.99$, the ZLB is slack even in the low-rate state. If anything, in this case capital requirements have an overall positive effect on equilibrium franchise values. In contrast, in the baseline calibration with $\beta_{L}=1.005$, the ZLB binds and higher capital requirements erode profitability, consistent with the discussion in Section 4.3. Note that in contrast to the static model, in the dynamic model franchise values depend on a bank's continuation value $\mathbb{E}\left[V_{t+1}\right]$. Thus, the adverse effect of capital requirements on franchise values is stronger, the higher $P_{L L}$, i.e. the longer the economy remains at the ZLB in expectation.

The right panel of Figure 5 illustrates the implications for equilibrium monitoring. 
Franchise Value $V_{L}$

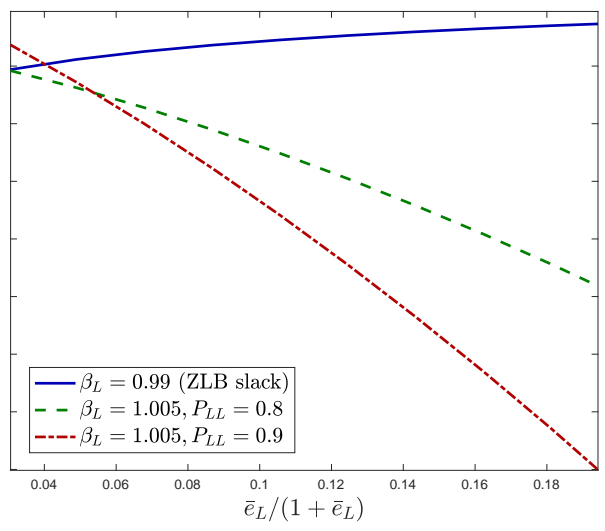

Failure Probability $1-q\left(m_{L}\right)$

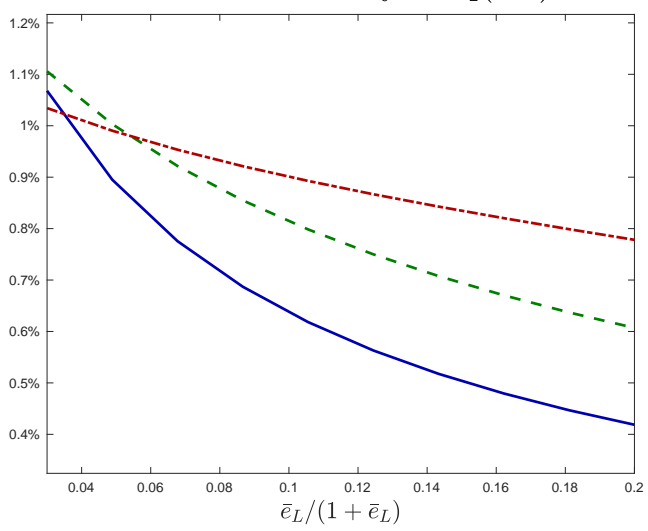

Figure 5: This figure plots franchise values (left panel) and risk-taking (right panel) in the low-rate state, against the capital requirement $\bar{e}_{L}$. Different lines represent different levels of discount factors $\beta_{L}$ and thus real rates, as well as different probabilities of remaining in the low-rate state $P_{L L}$. Parameters are otherwise calibrated as described in Section 5.1.

The more capital requirements depress franchise values, the less they curb risk-taking incentives. For example, franchise values drop much more with $\beta_{L}=1.005$ and $P_{L L}=0.9$ than in the baseline calibration with $\beta_{L}=1.005$ and $P_{L L}=0.8$. Accordingly, the line representing $P_{L L}=0.9$ in the right panel is flatter, i.e. a marginal increase in capital requirements reduces risk-taking incentives relatively less.

Via the skin-in-the-game effect, higher capital requirements reduce risk-taking (Proposition 3). However, at the ZLB, a negative franchise value effect renders capital requirements overall less effective, especially if the ZLB is expected to bind for a long time.

\section{Optimal Capital Regulation}

The previous analysis highlights two key positive insights: one, the ZLB can increase bank risk-taking incentives; two, the ZLB can make capital requirements less effective in reducing risk-taking incentives. Thus, capital regulation may be less effective during times when risk-taking incentives are already high. The natural follow-up question addressed in this section is what this means for optimal capital regulation. 


\subsection{Welfare Benchmark}

To answer this question, I calculate the welfare-maximizing, state-dependent levels $\left\{e_{H}^{*}, e_{L}^{*}\right\}$. An advantage of the general equilibrium approach here is that the representative household's lifetime utility delivers a clear welfare benchmark. Welfare can be computed recursively from the household's value function

$$
U_{t}=\max _{C_{t}, I_{t}^{m}, M_{t}, B_{t}, D_{t, i}} C_{t}+\gamma v\left(X_{t}\right)+\beta_{t} U_{t+1}
$$

Optimal capital requirements are defined as those that maximize the household's lifetime utility. To be clear about the constrained efficiency exercise, the approach takes as given the level of competition and deposit insurance, i.e. they are not part of the policy choice set. I also do not consider policies that would directly alleviate the ZLB constraint altogether, such as abolishing money.

\subsection{Results}

Figure 6 plots the welfare-maximizing capital requirements for different levels of the household's discount factor in the low-rate state $\beta_{L}$. When $\beta_{L}<\beta_{L}^{Z L B}$, interest rates are high and the ZLB is slack. In this region, the optimal capital requirement is around $13 \%-14 \%$ in both the low-rate and high-rate state, somewhat above the level currently required according to the Basel III regulatory framework. ${ }^{24}$

\footnotetext{
${ }^{24}$ In the model, the capital requirement is expressed as a fraction of non risk-weighted assets, more closely resembling the Leverage Ratio requirement. At the same time, in the model banks only invest in risky loans, which tend to carry relatively high regulatory risk-weights. The model capital requirement can therefore be interpreted as a leverage requirement on risky loans, somewhere between a leverage and a capital requirement. According to Basel III regulation, banks are required to hold Tier 1 plus Additional Tier 1 capital of 6\%, plus an additional 2.5\% in the "Capital Conversation Buffer", all as a fraction of risk-weighted assets (BIS, 2011). Moreover, Basel III requires a "Leverage Ratio" of at least $3 \%$ of Tier 1 capital over total (non risk-weighted) assets.
} 


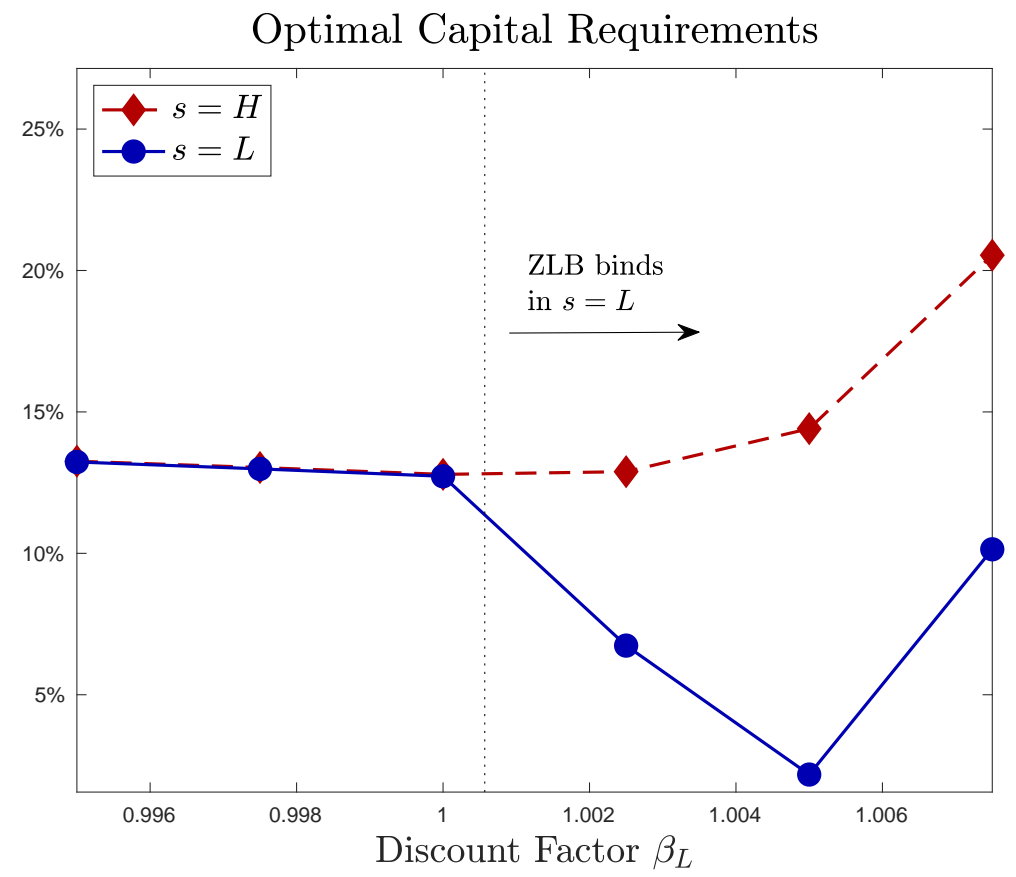

Figure 6: This figure plots optimal state-dependent capital requirements, for different levels of the discount factor in the low-rate state. Capital requirements are expressed as a fraction of total assets $\left(e_{t} /\left(1+e_{t}\right)\right)$. Parameters are calibrated as described in Section 5.1.

In contrast, when the ZLB binds in the low-rate state $\left(\beta_{L}>\beta_{L}^{Z L B}\right)$, the optimal capital requirement in the low-rate state drops significantly while that in the high-rate state increases. That is, if the ZLB binds occasionally, optimal dynamic capital requirements are positively correlated with the level of interest rates, with optimal requirements of $15 \%$ and above in the high-rate state but well below $10 \%$ in the low-rate state.

What explains these results? The benefit of tighter capital requirements is that they induce banks to take less risk (see Proposition 3 and Fig. 5). The cost of higher capital requirements is that they result in lower liquidity provision in the form of deposits in equilibrium. Optimal regulation trades off these two forces.

Figure 7 illustrates equilibrium risk-taking and liquidity provision in the baseline competitive equilibrium and compares to optimal requirements and the first best. If the ZLB is slack at all times, banks tend to take too much risk and provide too little liquidity relative to the first best. In this region, optimal capital requirements trade off a reduction 

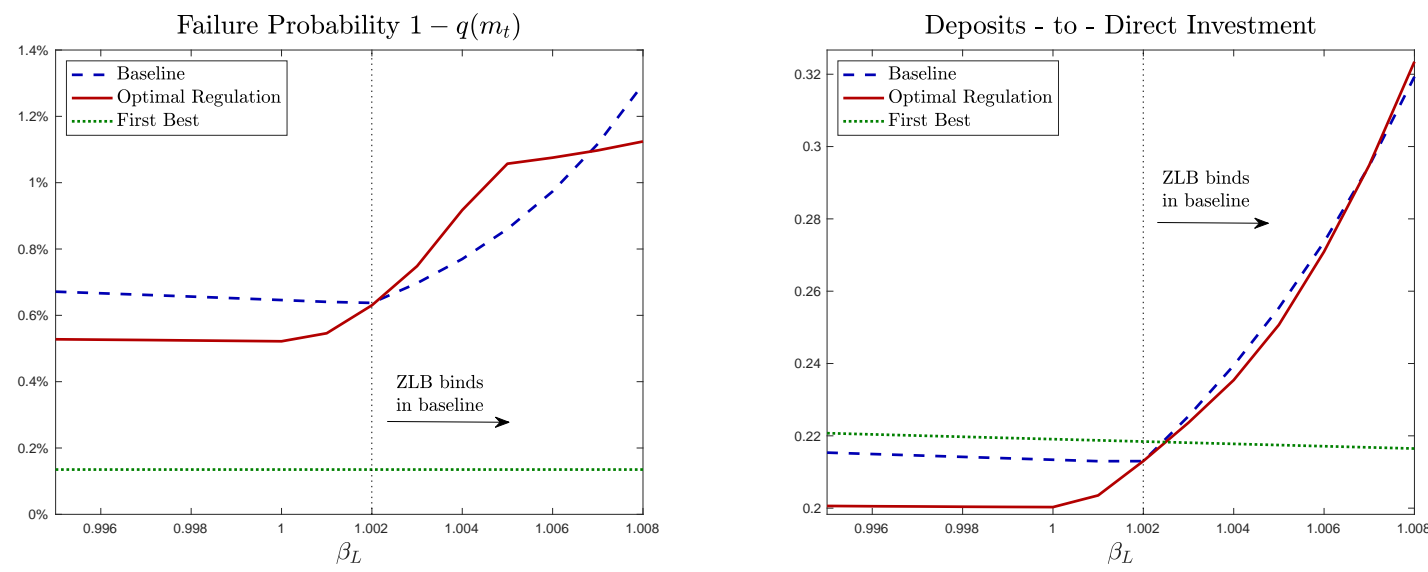

Figure 7: These graphs plot failure probabilities and liquidity provision for the first best, the competitive equilibrium with optimal capital requirements, and for the baseline with capital requirements of $8.5 \%$. The vertical dotted line marks the threshold $\beta_{L}^{Z L B}$, beyond which the ZLB binds in the low-rate state. Parameters are calibrated as described in section 5.1.

in risk-taking against lower liquidity provision, resulting in an optimal level around 13\% when the ZLB is slack.

When the ZLB binds occasionally $\left(\beta_{L}>\beta_{L}^{Z L B}\right)$, two new effects come into play. First, the franchise value effect described in Section 4.3 renders capital requirements less effective in curbing risk-taking at the ZLB. Because capital requirements have a cost, this effect motivates weaker regulation in the low-rate state, explaining the drop in $e_{L}^{*}$ for $\beta_{L}>\beta_{L}^{Z L B}$ in Figure $6 .^{25}$

At the same time, the binding ZLB in the low-rate state motivates a tighter capital requirement in the high-rate state, as evident by the increasing $e_{H}^{*}$ in Figure 6 . In the high-rate state, the effectiveness of capital requirements is not undermined because the ZLB is slack. Yet, risk-taking incentives are heightened because banks anticipate they may be constrained by the ZLB in the future, lowering franchise value. To tame these

\footnotetext{
${ }^{25}$ What explains the U-shaped pattern of the optimal capital requirement $e_{L}^{*}$ in Figure 6? The marginal return to monitoring is higher at lower levels of $m_{t}$, i.e. $q\left(m_{t}\right)-c\left(m_{t}\right)$ is concave. While the franchise value effect initially motivates a lower level of $e_{L}^{*}$, for very high levels of $\beta_{L}$ bank risk-taking is so strong that the marginal return to monitoring is very high and it becomes optimal to again increase the capital requirement as $\beta_{L}$ increases further.
} 
heightened risk-taking incentives, optimal capital requirements in the high-rate state are unambiguously tighter.

The left panel of Figure 7 reveals risk-taking under optimal regulation may be even higher than that in the baseline with capital requirements of $8.5 \%$. As capital requirements become less effective at the ZLB, it is optimal to allow more risk-taking, even though risk-taking incentives are already high.

Regarding liquidity provision, note that, at the ZLB, the equilibrium quantity of deposits grows relative to the financial market and may even exceed the first best level (right panel of Figure 7). Intuitively, from the perspective of households deposits become quite attractive when the ZLB binds, inducing a substitution from the financial market towards deposits.

Discussion The results in this section relate to the debate on counter-cyclical capital regulation. Recent contributions show that counter-cyclical leverage limits may be motivated in models with welfare-relevant pecuniary externalities (e.g. Lorenzoni, 2008; Stein, 2012; Korinek and Simsek, 2016). In the policy debate, a common rationale is that buffers built up in good times should be available to be used in bad times (e.g. Goodhart et al., 2008).

None of these channels are active in this model, as there are no fire sale or aggregate demand externalities or frictions in raising equity that would motivate dynamically adjusting optimal capital requirements. Yet, capital requirements optimally vary with the level of interest rates. The argument here is based purely on how the level of interest rates affects the ability of banks to adjust deposit rates in response to tighter regulation. To the extent that interest rates are low in bad times, the model thus delivers a novel rationale for counter-cyclical regulation. 


\subsection{Interaction with (Unconventional) Monetary Policy}

Another implication of the franchise value effect is that monetary- and macro-prudential policy may not be seen in isolation. In the policy debate, it is sometimes argued that monetary policy should focus on targeting inflation, while macro-prudential policies should target financial stability (e.g. Bernanke, 2015). This argument sees monetary policy as an independent tool relative to macro-prudential regulation. However, if near-zero interest rates undermine the effectiveness of prudential policies, monetary- and macro-prudential policy cannot be set in isolation, and their inter-dependencies need to be taken into account.

For example, a higher inflation target could overcome the problem altogether, by pushing up nominal rates. Figure 9 in Appendix A.7 shows that changes in inflation have a similar effect on optimal capital requirements compared to changes in discount factors shown in Figure 6.

\subsubsection{Subsidized Refinancing Operations}

While a higher inflation target may be a solution to the ZLB problem, achieving higher inflation may not be desirable due to costs not captured by the model. Even if a higher inflation level is desirable, it may not be feasible to implement it, as the experiences in Japan and more recently the Eurozone have shown. An alternative unconventional monetary policy tool may be refinancing operations, where the central bank provides cheap funding to banks. For example, the ECB has provided banks with funding at negative interest rates through its LTRO program.

Such refinancing operation can be introduced to the model as follows. Suppose that whenever the ZLB binds, the central bank provides funding at a low real rate of $r_{t+1}^{r e f i}$, up to a fraction $k_{t}$ of deposits. Banks that pick up the funding have an investment scale of $I_{t}^{b}=\left(1+e_{t}+k_{t}\right) D_{t}$, and their profits are given by (changes to the baseline model are 

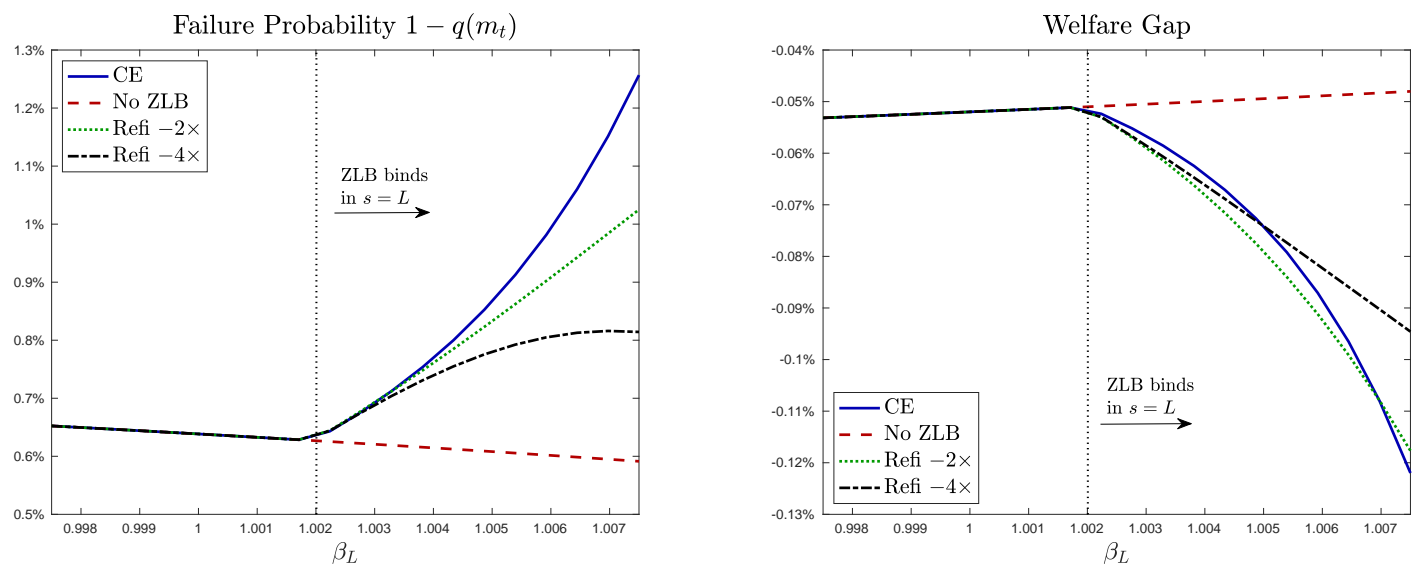

Figure 8: These graphs plot failure probabilities and welfare gaps for the baseline competitive equilibrium ("CE"), a counterfactual equilibrium without a ZLB friction ("No ZLB"), and the equilibrium with central bank refinancing operations for different levels of refinancing rates $r_{t+1}^{r e f i}$. Parameters are calibrated as described in Section 5.1.

highlighted in red)

$$
\Pi_{t, t+1}^{b}=q\left(m_{t}\right) \beta_{t}\left[r_{t+1}^{k}\left(1+e_{t}+k_{t}\right)-r_{t+1}^{d}-k_{t} r_{t+1}^{r e f i}\right]-\left[e_{t}+\left(1+e_{t}+k_{t}\right)\left(\psi_{1}+c\left(m_{t}\right)\right] .\right.
$$

Banks use the funding only if $r_{t+1}^{r e f i}$ is sufficiently low and satisfies

$$
q\left(m_{t}\right) \beta_{t}\left[r_{t+1}^{k}-r_{t+1}^{r e f i}\right]-\left(\psi_{1}+c\left(m_{t}\right) \geq 0\right.
$$

If all banks pick up the refinancing operation, taxes are now given by

$$
T_{t}=\left(1-q\left(m_{t-1}\right)\right) r_{t}^{d} D_{t-1}+\frac{M_{t-1}}{\pi_{t}}-M_{t}+k_{t} D_{t}-q\left(m_{t-1}\right) k_{t-1} r_{t}^{r e f i} D_{t-1}
$$

All other equilibrium conditions are unaffected.

Figure 8 compares the competitive equilibrium with and without refinancing operations to a counter-factual economy in which households do not have access to money, so deposit rates are not subject to a ZLB friction.

The refinancing rate is set proportionally to the "shadow deposit rate", which banks would set if there was no ZLB friction. In the figure, the line labeled "Refi $-2 \times$ " refers to an equilibrium in which the nominal refinancing rate is set to minus two times the gap between the equilibrium deposit rate and the shadow deposit rate. This translates to 
nominal refinancing rates between $0 \%$ and $-1 \%$. In the "Refi $-4 \times$ " economy, nominal refinancing rates go as low as $-2 \%$. Similarly, $k$ is set to 0 at $\beta_{L}=1.002$ and linearly increases to $k=0.2$ at $\beta_{L}=1.0075$, as shadow deposit rates become increasingly negative.

Negative-rate refinancing operations are effectively a subsidy for banks that improve profitability and franchise values. Accordingly, they restore incentives, as illustrated in the left panel of Figure 8. The lower the refinancing rate, the more risk-taking incentives are dampened. With very low refinancing rates, equilibrium risk-taking incentives can be restored relatively well and move closely to the shadow equilibrium absent the ZLB friction.

However, the overall welfare effect of refinancing operations is ambiguous. The right panel plots a welfare gap, defined as the relative deviation of the representative household's lifetime utility from the first best. When rates are very low ( $\beta_{L}$ high), the subsidy result in a higher level of welfare. However, for smaller values of $\beta_{L}$ the subsidy can actually worsen welfare. The reason is that the subsidized funding induces banks to grow inefficiently large relative to the financial market. Banks already grow relative to the financial market, when the lower bound on deposit rates makes deposits more attractive relative to direct investments via the financial market. This effect is amplified if additionally the central bank increases the funding supply available to banks through unconventional monetary policy.

Another negative effect may be that taxes raised to fund the subsidy may be distortionary (outside the model, as here taxes are lump-sum). Overall, while refinancing operations do well in restoring risk-taking incentives, their welfare effects are ambiguous due to the additional distortions introduced. 


\section{Conclusion}

Since the 1980s, real interest rates across advanced economies have followed a steady downward trend. Low rates are likely here to stay (Summers, 2014), increasing the likelihood that short-term rates frequently hit zero in the future. This new environment of near-zero interest rates requires re-thinking some fundamental questions across macro- and financial economics. This paper presents a model that highlights potential consequences for banking regulation and risk-taking and their interaction with (unconventional) monetary policy.

The ZLB may increase risk-taking incentives of banks, as low margins induce a search for yield when banks cannot pass on low asset returns to depositors. These effects are particularly strong if the ZLB is expected to bind for a long time. And even after monetary policy "normalization", incentives are affected if the ZLB is expected to bind again in the future.

While the ZLB has often been discussed as a constraint to monetary policy, this paper shows it can also impede the effectiveness of banking regulation. The ZLB not only increases risk-taking incentives per se, but it can also makes the typical regulatory tools employed to curb risk-taking less effective.

Perhaps surprisingly, even though there is already more risk-taking at the ZLB, these channels motivate optimally weaker requirements when the ZLB binds. On the other hand, optimal requirements should be tightened when the ZLB is slack today, but there is a chance of it binding in the future. The model thus provides a novel rationale for cyclically adjusting regulation.

These points are also relevant for the debate on the interaction between monetary and macro-prudential policies. It is sometimes argued that monetary policy should focus on inflation, while macro-prudential policies should focus on financial stability. However, if there is an interaction between the two, they cannot be seen in isolation. This paper 
highlights how a higher inflation target and unconventional monetary policies in the form of subsidized refinancing operations can complement capital regulation at the ZLB. An interesting avenue for future research is to explore further the joint determination of optimal monetary policy and banking regulation. 


\section{References}

Acharya, V. and G. Plantin (2016). Monetary easing and financial instability. Technical report, mimeo NYU Stern and Sciences Po.

Ahnert, T. and E. Perotti (2017). Intermediaries as safety providers. Technical report, University of Amsterdam Working Paper.

Ampudia, M. and S. Van den Heuvel (2018). Monetary policy and bank equity values in a time of low interest rates.

Azar, J., S. Raina, and M. C. Schmalz (2016). Ultimate ownership and bank competition.

Begenau, J. (2016). Capital requirements, risk choice, and liquidity provision in a business cycle model.

Bernanke, B. (2015). Should monetary policy take into account risks to financial stability?

BIS (2011). A global regulatory framework for more resilient banks and banking systems. Technical report.

Boyd, J. H. and G. De Nicolo (2005). The theory of bank risk taking and competition revisited. The Journal of finance 60(3), 1329-1343.

Brunnermeier, M. K. and Y. Koby (2018). The reversal interest rate. Technical report, National Bureau of Economic Research.

Brunnermeier, M. K. and Y. Sannikov (2014). A macroeconomic model with a financial sector. American Economic Review 104(2), 379-421.

Dang, T. V., G. Gorton, B. Holmström, and G. Ordonez (2017). Banks as secret keepers. The American Economic Review 107(4), 1005-1029.

Davydiuk, T. (2017). Dynamic bank capital requirements. 
Dell Ariccia, G., L. Laeven, and R. Marquez (2014). Real interest rates, leverage, and bank risk-taking. Journal of Economic Theory 149, 65-99.

Diamond, D. W. (1984). Financial intermediation and delegated monitoring. The review of economic studies 51(3), 393-414.

Diamond, D. W. and P. H. Dybvig (1983). Bank runs, deposit insurance, and liquidity. Journal of political economy $91(3), 401-419$.

Dixit, A. K. and J. E. Stiglitz (1977). Monopolistic competition and optimum product diversity. The American Economic Review 67(3), 297-308.

Drechsler, I., A. Savov, and P. Schnabl (2017a). The deposits channel of monetary policy. The Quarterly Journal of Economics 132(4), 1819-1876.

Drechsler, I., A. Savov, and P. Schnabl (2017b). A model of monetary policy and risk premia. The Journal of Finance.

Drechsler, I., A. Savov, and P. Schnabl (2018). Banking on deposits: Maturity transformation without interest rate risk. Technical report, National Bureau of Economic Research.

Eggertsson, G. B., R. E. Juelsrud, L. H. Summers, and E. G. Wold (2019). Negative nominal interest rates and the bank lending channel. Technical report, National Bureau of Economic Research.

Eggertsson, G. B. and P. Krugman (2012). Debt, deleveraging, and the liquidity trap: A fisher-minsky-koo approach*. The Quarterly Journal of Economics 127(3), 1469-1513.

Eggertsson, G. B. and M. Woodford (2003). The Zero Bound on Interest Rates and Optimal Monetary Policy. Brookings Papers on Economic Activity 34(1), 139-235.

English, W. B., S. J. Van den Heuvel, and E. Zakrajšek (2018). Interest rate risk and bank equity valuations. Journal of Monetary Economics. 
Farhi, E. and I. Werning (2016). A theory of macroprudential policies in the presence of nominal rigidities. Econometrica 84(5), 1645-1704.

Gersbach, H. and J.-C. Rochet (2017). Capital regulation and credit fluctuations. Journal of Monetary Economics 90, 113-124.

Goodhart, C. et al. (2008). Liquidity risk management. Banque de France Financial Stability Review 11, 39-44.

Gorton, G. and G. Pennacchi (1990). Financial intermediaries and liquidity creation. The Journal of Finance 45(1), 49-71.

Guerrieri, V. and G. Lorenzoni (2017). Credit crises, precautionary savings, and the liquidity trap. The Quarterly Journal of Economics 132(3), 1427-1467.

Heider, F., F. Saidi, and G. Schepens (2019). Life below zero: Bank lending under negative policy rates. The Review of Financial Studies 32(10), 3728-3761.

Hellmann, T. F., K. C. Murdock, and J. E. Stiglitz (2000). Liberalization, moral hazard in banking, and prudential regulation: Are capital requirements enough? American Economic Review, 147-165.

Hoffmann, P., S. Langfield, F. Pierobon, and G. Vuillemey (2017). Who bears interest rate risk?

Holmstrom, B. and J. Tirole (1997, August). Financial intermediation, loanable funds, and the real sector. The Quarterly Journal of Economics 112(3), 663-91.

Jeanne, O. and A. Korinek (2018). Managing credit booms and busts: A pigouvian taxation approach. Journal of Monetary Economics.

Jiménez, G., S. Ongena, J.-L. Peydró, and J. Saurina (2014). Hazardous times for monetary policy: What do twenty-three million bank loans say about the effects of monetary policy on credit risk-taking? Econometrica 82(2), 463-505. 
Keynes, J. (1936). The general theory of employment, interest and money. Books for college libraries. Harcourt, Brace.

Korinek, A. and A. Simsek (2016). Liquidity trap and excessive leverage. The American Economic Review 106(3), 699-738.

Krugman, P. R. (1998). It's Baaack: Japan's Slump and the Return of the Liquidity Trap. Brookings Papers on Economic Activity 29(2), 137-206.

Lorenzoni, G. (2008). Inefficient credit booms. The Review of Economic Studies 75 (3), 809-833.

Malherbe, F. (2015). Optimal capital requirements over the business and financial cycles.

Martinez-Miera, D. and R. Repullo (2010). Does competition reduce the risk of bank failure? Review of Financial Studies 23(10), 3638-3664.

Martinez-Miera, D. and R. Repullo (2017). Search for yield. Econometrica 85(2), 351378.

Martinez-Miera, D. and J. Suarez (2014). Banks' endogenous systemic risk taking. manuscript, CEMFI.

Perotti, E. C. and J. Suarez (2002). Last bank standing: What do i gain if you fail? European economic review 46(9), 1599-1622.

Rajan, R. G. (2005). Has financial development made the world riskier? Technical report, National Bureau of economic Research.

Repullo, R. (2004). Capital requirements, market power, and risk-taking in banking. Journal of financial Intermediation 13(2), 156-182.

Repullo, R. and J. Suarez (2012). The procyclical effects of bank capital regulation. The Review of financial studies 26(2), 452-490. 
Salop, S. C. (1979). Monopolistic competition with outside goods. The Bell Journal of Economics, 141-156.

Scharfstein, d. and A. Sunderam (2015). Market power in mortgage lending and the transmission of monetary policy. Technical report.

Stein, J. C. (2012). Monetary policy as financial stability regulation. The Quarterly Journal of Economics 127(1), 57-95.

Summers, L. H. (2014). Us economic prospects: Secular stagnation, hysteresis, and the zero lower bound. Business Economics 49(2), 65-73.

Van den Heuvel, S. J. (2008). The welfare cost of bank capital requirements. Journal of Monetary Economics 55(2), 298-320.

Wang, O. (2018). Banks, Low Interest Rates, and Monetary Policy Transmission. pp. 90.

Xiao, K. (2017). Shadow banks, deposit competition, and monetary policy. Technical report. 


\section{A. Paper Appendix}

\section{A.1. Equilibrium conditions}

All equilibrium conditions can be summarized as follows:

- Firms

$$
\begin{aligned}
F\left(K_{t}, N_{t}\right) & =K_{t}^{\alpha} N_{t}^{1-\alpha}, \\
K_{t} & =\bar{q} I_{t-1}^{m}+q\left(m_{t}\right) I_{t-1}^{b}, \\
r_{t}^{k} & =\alpha\left(\frac{N_{t}}{K_{t}}\right)^{(1-\alpha)}, \\
w_{t} & =(1-\alpha)\left(\frac{K_{t}}{N_{t}}\right)^{(\alpha)} .
\end{aligned}
$$

- Households

$$
\begin{aligned}
r_{t+1}^{b} \beta_{t} & =1, \\
r_{t}^{b} & =\bar{q} r_{t}^{k}, \\
D_{t, i}\left(r_{t+1, i}^{d}\right) & = \begin{cases}{\left[\frac{\gamma v^{\prime}\left(D_{t}\right)}{1-r_{t+1, i}^{d} \beta_{t}}\right]^{\eta} D_{t},} & \text { if } r_{t+1, i}^{d} \geq 1 / \pi_{t+1}, \\
0 & , \text { else. } \\
C_{t} & =F\left(K_{t}, N_{t}\right)-I_{t}^{m}-I_{t}^{b}\left(1+c\left(m_{t}\right)+\psi_{1}\right) . \\
M_{t} & =B_{t}=0\end{cases}
\end{aligned}
$$


- Banks

$$
\begin{aligned}
c^{\prime}\left(m_{t}\right)\left(1+e_{t}\right) D_{t} & =q^{\prime}\left(m_{t}\right) \beta_{t}\left(\left[\left(1+e_{t}\right) R_{t+1}-r_{t+1}\right] D_{t}+\mathbb{E}_{t} V_{t+1}\right) . \\
\Pi_{t, t+1}^{b} & =q\left(m_{t, i}\right) \beta_{t}\left[r_{t+1}^{k}\left(1+e_{t, i}\right)-r_{t+1, i}^{d}\right]-\left[e_{t, i}+\left(1+e_{t, i}\right)\left(\psi_{1}+c\left(m_{t, i}\right)\right],\right. \\
\operatorname{div}_{t, i} & =\left[r_{t}^{k}\left(1+e_{t-1, i}\right)-r_{t, i}^{d}\right] D_{t-1, i}-\left[e_{t, i}+\left(1+e_{t, i}\right)\left(\psi_{1}+c\left(m_{t, i}\right)\right)\right] D_{t, i}, \\
r_{t+1, i}^{d} & =\max \left\{r_{t+1}^{d, i n t}, \frac{1}{\pi_{t+1}}\right\}, \\
r_{t+1}^{d, i n t} & =\frac{1}{\beta_{t}}\left[\frac{\eta \beta_{t} r_{t+1}^{k}-1}{\eta-1}-\frac{\eta}{\eta-1} \frac{\left(1-q\left(m_{t, i}\right) / \bar{q}\right) e_{t, i}+\left(1+e_{t, i}\right)\left(\psi_{1}+c\left(m_{t, i}\right)\right)}{q\left(m_{t, i}\right)}\right] . \\
V_{t} & =\max _{m_{t}, e_{t}, r_{t+1}} \Pi_{t, t+1}^{b} D_{t}\left(r_{t+1}, m_{t}\right)+q\left(m_{t}\right) \beta_{t} \mathbb{E}_{t} V_{t+1}, \\
I_{t}^{b} & =\left(1+e_{t}\right) D_{t}, \\
e_{t} & =\bar{e}_{t} .
\end{aligned}
$$

- Government

$$
\begin{aligned}
& \pi_{t}=\pi, \\
& T_{t}=\left(1-q\left(m_{t-1}\right)\right) r_{t}^{d} D_{t-1}+\frac{M_{t-1}}{\pi_{t}}-M_{t} .
\end{aligned}
$$

- Fisher Equations

$$
\begin{aligned}
& i_{t}^{d}=r_{t}^{d} \pi_{t}, \\
& i_{t}^{k}=r_{t}^{k} \pi_{t}, \\
& i_{t}^{b}=r_{t}^{b} \pi_{t} .
\end{aligned}
$$

\section{A.2. First Best}

This appendix characterizes the first best allocation (FB) and contrast it to the competitive equilibrium (CE). The first best allocation is the allocation chosen by a planner's problem, who directly chooses risk-taking, consumption and investment, subject to aggregate resource constraints. 
From the CES aggregator it follows immediately that the planner allocates the same amount of deposit funding to each bank, $D_{t, i}=D_{t}$. Relative to equity, deposits have the advantage of generating convenience utility. In the competitive equilibrium, equity fulfills the role of reducing the risk-taking incentives of banks, but in the first best banks are optimally purely deposit-funded, so $e_{t}=0$. The remaining variables follow from the following planner problem

$$
\begin{aligned}
\max _{C_{t}, I_{t}^{m}, D_{t}, m_{t}} & \mathbb{E}_{0} \sum_{t=0}^{\infty}\left(\prod_{\tau=0}^{t-1} \beta_{\tau}\right)\left[C_{t}+\gamma v\left(X_{t}\right)\right] \\
\text { with } & X_{t}=M_{t}+D_{t}, \\
\text { s.t. } & C_{t}+I_{t}^{m}+I_{t}^{b}\left(1+\psi_{1}+c\left(m_{t}\right)\right)=F\left(K_{t}, N_{t}\right), \\
& I_{t}^{b}=\left(1+e_{t}\right) D_{t}, \\
& K_{t}=q\left(m_{t-1}\right) I_{t-1}^{b}+\bar{q} I_{t-1}^{m}
\end{aligned}
$$

The first-order conditions w.r.t. $I_{t}^{m}, m_{t}$ and $D_{t}$ can be combined as follows:

$$
\begin{aligned}
\beta_{t} \bar{q} F_{K}\left(K_{t+1}, N_{t+1}\right) & =1 \\
c^{\prime}\left(m_{t}\right) & =\frac{q^{\prime}\left(m_{t}\right)}{\bar{q}} \\
D_{t} & =\frac{\gamma}{1-q\left(m_{t}\right) / \bar{q}+\psi_{1}+c\left(m_{t}\right)}
\end{aligned}
$$

These three conditions are readily compared to their counterparts in the competitive equilibrium. First, Eq. (21) is equivalent to the household's Euler Equation (4), once combined with the no-arbitrage condition (5). Thus, the investment in financial markets is not distorted.

In contrast, Condition (22) differs from its counterparts in the CE. In the FB allocation, $c^{\prime}\left(m_{t}\right)=q^{\prime}\left(m_{t}\right) / \bar{q}$. This is not generally true in the CE. As can be seen from the bank's FOC w.r.t monitoring (11), the bank's monitoring decision does not generally align with the FB, and depends on capital, interest margins and continuation value.

Similarly, Condition (23) can be compared to the demand for deposits by households 
in Eq. (6), which can be re-written as

$$
D_{t}=\frac{\gamma}{1-q\left(m_{t}\right) \frac{r_{t+1}^{d}}{r_{t+1}^{b}}}
$$

The equilibrium level of deposits in the $\mathrm{CE}$ is only equal to the FB level if $\frac{r_{t+1}}{R_{t+1}}=$ $\frac{1}{\bar{q}}-\frac{\psi_{1}+c\left(m_{t}\right)}{q\left(m_{t}\right)}$. This is not generally true, see Eq. (12).

These two comparisons show that misallocations arise because banks do not choose the optimal amount of risk-taking and do not provide the optimal amount of liquidity services via deposits. Limited liability gives bank shareholders an option-like payoff, as they do not fully internalize losses incurred in case of failure. This convex payoff structure induces excessive risk-taking. On the other hand, monopolistic competition implies that banks may take less risk relative to the FB. The reason is that the bank's franchise value reflects rents due to market power, which are of private value to bank shareholders but do not add to welfare. Overall, bank shareholders trade off the gains from shifting risk on depositors against the risk of loss of franchise value. In the baseline calibration, banks take excessive risk relative to the first best.

While market power may reduce those excessive risk-taking incentives, it also reduces the liquidity provision by banks. Low deposit rates weaken the demand for deposits by households, resulting in an inefficiently low quantity of liquidity creation in equilibrium.

\section{A.3. Salop Model of Competition}

This appendix derives equilibrium deposit rates under a circular road competition model as in Salop (1979). Suppose households are uniformly distributed on a unit circle, and there are $n$ banks located symmetrically on the circumference of the circle. Traveling to banks has a cost $\mu$ per unit of distance to households. I focus on symmetric Nashequilibria where all banks set the same deposit rate $r_{t, i}^{d}=r_{t}^{d}$ for all $i$. 


\section{A.3.1. Deposit Demand}

To derive the demand for deposits of bank $j$, consider a household that is located between bank $j$ and bank $j+1$, at a distance $z$ away from bank $j$ and $\left(\frac{1}{n}-z\right)$ from bank $j+1$. This household is indifferent between depositing at bank $j$ and $j+1$

$$
r_{t+1, j}^{d}-\mu z=r_{t+1, j+1}^{d}-\left(\frac{1}{n}-z\right) \mu \text {. }
$$

Now consider an equilibrium in which $r_{t+1, i}^{d}=r_{t+1}^{d}$ for all $i \neq j$. Solving condition (25) for $z$ yields the depositor located at distance $\hat{z}$, who is indifferent between depositing at bank $j$ and bank $j+1$,

$$
\hat{z}=\frac{1}{2 n}+\frac{r_{t+1, j}^{d}-r_{t+1}^{d}}{2 \mu}
$$

By offering a deposit rate $r_{t+1, i}^{d}$, bank $i$ can attract a mass $2 z$ of depositors, so the demand for deposits of bank $j$ is given by (as long as the ZLB is slack, i.e. for $r_{t+1, i}^{d} \geq 1 / \pi_{t+1}$ )

$$
D\left(r_{t+1, i}^{d}\right)=2 \hat{z} D_{t}=\left[\frac{1}{n}+\frac{r_{t+1, i}^{d}-r_{t+1}^{d}}{\mu}\right] D_{t},
$$

where $D_{t}$ is the aggregate demand for deposits. Intuitively, the demand for deposits of bank $j$ decreases in the number of banks $n$ on the circle, and increases in the deposit rate it offers relative to other banks on the circle.

\section{A.3.2. Deposit Rate}

The bank's problem is as in Eq. (8), but the demand for deposits is now given by Eq. (26) instead of (6). The bank's FOC w.r.t. $r_{t+1, i}^{d}$ is

$$
\frac{\partial V_{t}}{\partial r_{t+1, i}^{d}}=-q\left(m_{t}\right) \beta_{t} D_{t}+\Pi_{t, t+1} \frac{\partial D_{t, i}\left(r_{t+1, i}^{d}\right)}{\partial r_{t+1}^{d}}=0
$$

with the partial derivative now given by

$$
\frac{\partial D_{t, i}\left(r_{t+1, i}^{d}\right)}{\partial r_{t+1}^{d}}=\frac{D_{t}}{\mu}
$$


Combining the two, and rearranging yields the following interior solution for the deposit rate:

$$
r_{t+1, i}^{d}=\frac{1}{\mu}\left(r_{t+1}^{k}\left(1+e_{t, i}\right)-\frac{1}{\beta_{t}}\left[\frac{e_{t, i}+\left(1+e_{t, i}\right)\left(\psi_{1}+c\left(m_{t, i}\right)\right.}{q\left(m_{t}\right)}\right]\right) .
$$

This expression is almost identical to the interior deposit rate set under monopolistic competition in Eq. (12). The key difference is that here market power is governed by the cost of traveling to banks $\mu$, rather than the elasticity of substitution between deposit varieties $\eta$.

Section 5.2 highlights the importance of the ratio $\frac{r_{t+1}^{d}}{r_{t+1}^{b}}$ for the results in Propositions 1 , 2, and 3. In the Salop model, this ratio si given by

$$
\frac{r_{t+1}^{d}}{r_{t+1}^{b}}= \begin{cases}\frac{1}{\mu \bar{q}}-\frac{1}{\mu} \frac{\left(1-q\left(m_{t, i}\right) / \bar{q}\right) \bar{e}_{t}+\left(1+\bar{e}_{t}\right)\left(\psi_{1}+c\left(m_{t, i}\right)\right)}{q\left(m_{t, i}\right)} & , \text { if } \beta_{t} \leq \beta_{t}^{Z L B} \\ \beta_{t} / \pi_{t+1} & , \text { else. }\end{cases}
$$

This expression can be readily compared to Eq. (18) in the main text. Importantly, in the Salop model, the ratio behaves in the same way as under monopolistic competition. If and only if the ZLB is slack, banks can pass on lower rates or tighter capital requirements to depositors. This comparison shows that the key results in the paper are robust to using the model by Salop (1979), as an alternative to the monopolistic competition setup of Dixit and Stiglitz (1977).

\section{A.4. Model without Deposit Insurance}

In the model, risk-taking incentives are distorted due to the presence of deposit insurance. This appendix shows that a similar distortion is the outcome in a model without deposit insurance, but where instead monitoring incentives are not contractible, and that banks sequentially first raise funding, and then decide on monitoring.

Absent deposit insurance, the demand for deposits is also a function of monitoring, as depositors demand to be compensated for the risk banks take. Thus, the household's 
budget constraint changes to

$$
C_{t}+I_{t}^{m}+M_{t}+B_{t}+\int_{0}^{1} D_{t, i} d i=r_{t}^{b} B_{t-1}+r_{t}^{k} \hat{I}_{t-1}^{m}+\frac{M_{t-1}}{\pi_{t}}+\int_{0}^{1} q\left(m_{t, i}\right) r_{t, i}^{d} D_{t-1, i} d i+d i v_{t}+w_{t} N_{t}-T_{t}
$$

and the demand for deposits is given by

$$
D_{t, i}\left(r_{t+1, i}^{d}, m_{t, i}\right)= \begin{cases}{\left[\frac{\gamma v^{\prime}\left(D_{t}\right)}{1-q\left(m_{t, i}\right) r_{t+1, i}^{d} \beta_{t}}\right]^{\eta} D_{t}} & , \text { if } r_{t+1, i}^{d} \geq 1 / \pi_{t+1} \\ 0 & , \text { else. }\end{cases}
$$

Because monitoring is not contractible, the bank problem (8) is now subject to the following additional incentive-compatibility constraint

$$
m_{t, i}=\arg \max _{m_{t, i}} \Pi_{t, t+1}^{b} D_{t, i}\left(r_{t+1, i}^{d}\right)+q\left(m_{t, i}\right) \beta_{t} \mathbb{E}_{t} V_{t+1}
$$

Since a bank decides sequentially on its funding and then monitoring, the problem is solved backwards, starting with the optimal monitoring choice for a given level of $D_{t, i}$ and $e_{t, i}$. The incentive-compatible $m_{t}$ is characterized by the first order condition to (31):

$$
c^{\prime}\left(m_{t, i}\right)\left(1+e_{t, i}\right) D_{t, i}=q^{\prime}\left(m_{t, i}\right) \beta_{t}\left(\left[\left(1+e_{t, i}\right) R_{t+1}-r_{t+1, i}\right] D_{t, i}+\mathbb{E}_{t} V_{t+1}\right)
$$

This condition is equivalent to (11). Thus, under the assumption that monitoring is not contractible and chosen after raising funding, risk-taking is distorted in the same way as under deposit insurance.

\section{A.5. Proof of Proposition 3}

Proof. Taking a derivative of the RHS of Eq. (17) w.r.t. $\bar{e}_{t}$ :

$$
\begin{aligned}
\frac{d R H S}{d \bar{e}_{t}}= & \frac{1}{\bar{q}}-\frac{\partial\left(r_{t+1}^{d} / r_{t+1}^{b}\right)}{\partial \bar{e}_{t}} \\
& = \begin{cases}\frac{1}{\bar{q}}+\frac{\eta}{(\eta-1)} \frac{1}{q\left(m_{t}\right)}\left(1+\psi_{1}+c\left(m_{t}\right)-\frac{q\left(m_{t}\right)}{\bar{q}}\right) & , \text { if } \beta_{t}<\beta_{t}^{Z L B} \\
\frac{1}{\bar{q}} & \text {, else. }\end{cases}
\end{aligned}
$$

Thus, the RHS is shifted upward more in response to an increase in $\bar{e}_{t}$ if the ZLB is slack, resulting in a stronger equilibrium response of $m_{t}$ to changes in $\bar{e}_{t}$. 


\section{A.6. Calibration}

Table 1 summarizes the calibration of the model and data sources.

Table 1: Calibration

\begin{tabular}{|c|c|c|}
\hline Parameter & Target Moment & Data Source \\
\hline$\pi=1.02$ & Inflation Target of $2 \%$ & Fed \\
\hline$\beta_{H}=0.975$ & $\begin{array}{l}\text { Average } 5 \text {-year Treasury } 1996-2008 \text { of } 4.6 \%, i_{H}^{b}= \\
1.046\end{array}$ & FRED \\
\hline$\beta_{L}=1.005$ & $\begin{array}{l}\text { Average corporate bond yield } 2009-2015 \text { of } 1.5 \% \text {, } \\
i_{L}^{b}=1.015\end{array}$ & FRED \\
\hline$\alpha=0.33$ & Income share to capital $1 / 3$ & Kaldor Fact \\
\hline $\bar{e}_{t}=0.0929$ & Basel III bank capital requirement, $\bar{e}_{t} /\left(1+\bar{e}_{t}\right)=8.5 \%$ & BIS \\
\hline$\psi_{1}=0.024$ & $\begin{array}{l}\text { Aggregate U.S. bank non-interest expense / assets } \\
1996-2017 \text { of around } 3 \%\end{array}$ & $\begin{array}{l}\text { FDIC Historical Bank } \\
\text { Data }\end{array}$ \\
\hline$\psi_{2}=0.0015$ & $\begin{array}{l}\text { Average annual failure rate of U.S. banks, } 1-q\left(m_{H}\right)= \\
0.76 \%\end{array}$ & Davydiuk (2017) \\
\hline$\eta=8$ & $\begin{array}{l}\text { Aggregate margin of U.S. banks from 1996-2008 } r_{H}^{k}- \\
r_{H}^{d}=3.3 \%\end{array}$ & $\begin{array}{l}\text { FDIC Historical Bank } \\
\text { Data }\end{array}$ \\
\hline$\gamma=0.0007$ & $\begin{array}{l}\text { Deposit liabilities of U.S. chartered institutions / total } \\
\text { debt liabilities of non-financial corporations, } D_{t} /\left(D_{t}+\right. \\
\left.I_{t}^{m}\right)=0.02\end{array}$ & Flow of Funds \\
\hline $\bar{q}=0.985$ & Average corporate bond spread 1996-2017: $1.54 \%$ & FRED \\
\hline$P_{H}=0.9$ & Expected duration in high-rate state of 10 years & $\mathrm{N} / \mathrm{A}$ \\
\hline$P_{L}=0.8$ & Expected duration in low-rate state of 5 years & $\mathrm{N} / \mathrm{A}$ \\
\hline
\end{tabular}




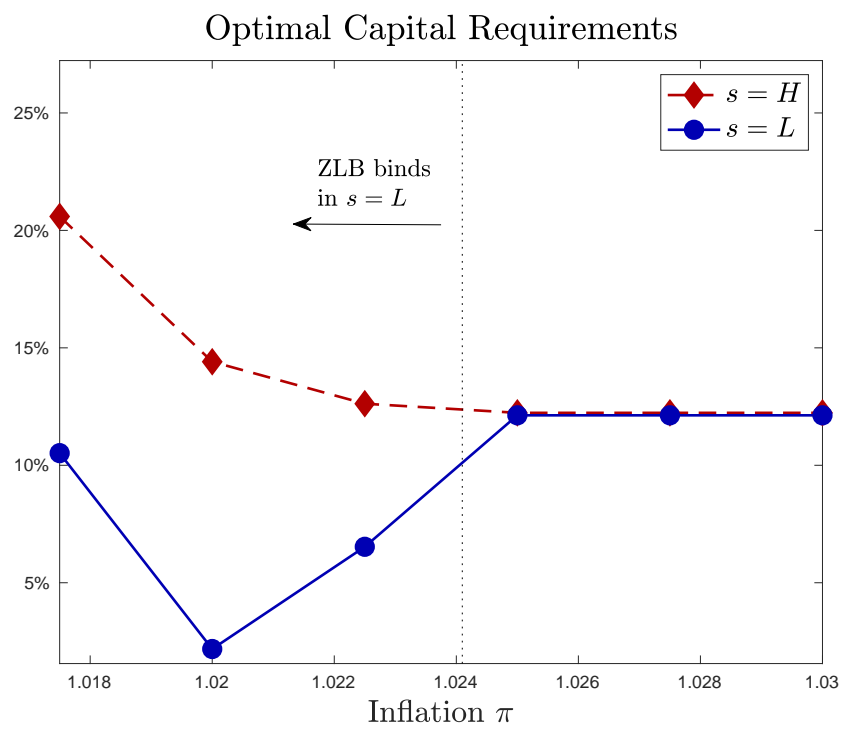

Figure 9: This figure plots optimal state-dependent capital requirements, for different levels of the inflation target $\pi$. Capital requirements are expressed as a fraction of total assets $\left(e_{t} /\left(1+e_{t}\right)\right)$. Parameters are calibrated as described in Section 5.1.

\section{A.7. Inflation and Optimal Capital Requirements}

Analogous to Figure 6 in the main text, Figure 9 derives optimal capital requirements for different level of inflation. The emerging picture is the mirror-image of that in Figure 6. For a sufficiently high inflation target above $2.4 \%$, the ZLB is slack and optimal capital requirements are around $13 \%$ in both the high- and low-rate state. With inflation below $2.4 \%$, optimal capital requirements vary with the level of interest rates. The reason for this is the same as discussed in Section 6. The difference here is that changes in $\pi$ affect nominal interest rates, keeping real rates fixed. It is intuitive that nominal rates matter, given that the ZLB is a nominal phenomenon. 